\title{
Belowground Biodiversity Relates Positively to Ecosystem Services of European Forests
}

\author{
Mark R. Bakker ${ }^{1,2 *}$, Ivano Brunner ${ }^{3}$, Francis Ashwood ${ }^{4}$, Brynhildur Bjarnadottir ${ }^{5}$, \\ Tom Bolger ${ }^{6}$, Isabella Børja ${ }^{7}$, Monique Carnol ${ }^{8}$, Pavel Cudlin ${ }^{9}$, Lise Dalsgaard ${ }^{10}$, \\ Amandine Erktan ${ }^{11,12}$, Douglas Godbold ${ }^{13}$, Hojka Kraigher ${ }^{14}$, Ina C. Meier ${ }^{12}$, \\ Luis Merino-Martín ${ }^{11,15}$, Jurga Motiejūnaité ${ }^{16}$, Tanja Mrak ${ }^{14}$, Edda S. Oddsdóttir ${ }^{17}$, \\ Ivika Ostonen ${ }^{18}$, Taina L. Pennanen ${ }^{19}$, Ülle Püttsepp ${ }^{20}$, Laura M. Suz ${ }^{21}$, \\ Elena I. Vanguelova ${ }^{4}$, Lars Vesterdal ${ }^{22}$ and Nadejda A. Soudzilovskaia ${ }^{23}$
}

${ }^{1}$ Bordeaux Sciences Agro, UMR 1391 ISPA, Gradignan, France, ${ }^{2}$ INRA, UMR 1391 ISPA, Villenave d'Ornon, France, ${ }^{3}$ Swiss Federal Institute for Forest, Snow and Landscape Research WSL, Birmensdorf, Switzerland, ${ }^{4}$ Forest Research, Alice Holt Lodge, Farnham, United Kingdom, ${ }^{5}$ Department of Education, University of Akureyri Iceland, Akureyri, Iceland, ${ }^{6}$ School of Biology and Environmental Science, University College Dublin, Dublin, Ireland, ${ }^{7}$ Department of Fungal Plant Pathology in Forestry, Agriculture and Horticulture, Norwegian Institute of Bioeconomy Research, Ås, Norway, ${ }^{8}$ InBios, Plant and Microbial Ecology, University of Liège, Liège, Belgium, ${ }^{9} \mathrm{Global}$ Change Research Institute CAS, České Budějovice, Czechia,

${ }^{10}$ Deptartment of Forest and Climate, Norwegian Institute of Bioeconomy Research, Ås, Norway, ${ }^{11}$ AMAP, INRA, Université de Montpellier, CIRAD, CNRS, IRD, Montpellier, France, ${ }^{12}$ Plant Ecology, University of Göttingen, Göttingen, Germany, ${ }^{13}$ Institute of Forest Ecology, Universität für Bodenkultur, Vienna, Austria, ${ }^{14}$ Slovenian Forestry Institute, Ljubljana, Slovenia, ${ }^{15}$ CEFE, CNRS, Univ Montpellier, Univ Paul Valéry Montpellier 3, EPHE, IRD, Montpellier, France, ${ }^{16}$ Nature Research Centre, Vilnius, Lithuania, ${ }^{17}$ Icelandic Forest Research, Mógilsá, Iceland, ${ }^{18}$ Department of Geography, Institute of Ecology and Earth Sciences, University of Tartu, Tartu, Estonia, ${ }^{19}$ Natural Resources Institute Finland, LUKE, Helsinki, Finland, ${ }^{20}$ Chair of Biodiversity and Nature Tourism, Estonian University of Life Sciences, Tartu, Estonia, ${ }^{21}$ Comparative Plant and Fungal Biology, Royal Botanic Gardens Kew, London, United Kingdom, ${ }^{22}$ Department of Geosciences and Natural Resource Management, University of Copenhagen, Copenhagen, Denmark, ${ }^{23}$ Environmental Biology Department, Institute of Environmental Sciences, Leiden University, Leiden, Netherlands

Biodiversity of ecosystems is an important driver for the supply of ecosystem services to people. Soils often have a larger biodiversity per unit surface area than what can be observed aboveground. Here, we present what is to our knowledge, the most extensive literature-based key-word assessment of the existing information about the relationships between belowground biodiversity and ecosystem services in European forests. The belowground diversity of plant roots, fungi, prokaryota, soil fauna, and protists was evaluated in relation to the supply of Provisioning, Regulating, Cultural, and Supporting Services. The soil biota were divided into 14 subgroups and the ecosystem services into 37 separate services. Out of the 518 possible combinations of biotic groups and ecosystem services, no published study was found for 374 combinations (72\%). Of the remaining 144 combinations (28\%) where relationships were found, the large majority $(87 \%)$ showed a positive relationship between biodiversity of a belowground biotic group and an associated ecosystem service. However, for the majority of the combinations (102) there were only three or fewer studies. The percentage of cases for which a relationship was detected varied strongly between ecosystem service categories with 23\% for Provisioning, 8\% for Regulating, 40\% for Cultural, and 48\% for Supporting Services. We conclude that (1) soil biodiversity is generally positively related to ecosystem services in European forests; (2) the links between soil biodiversity and Cultural or Supporting services are better documented than those relating to Provisioning and Regulating services; (3) there is a huge knowledge gap for most possible combinations 
of soil biota and ecosystem services regarding how a more biodiverse soil biota is associated with a given ecosystem service. Given the drastically increasing societal demand for knowledge of the role of biodiversity in the functioning of ecosystems and the supply of ecosystem services, we strongly encourage the scientific community to conduct well-designed studies incorporating the belowground diversity and the functions and services associated with this diversity.

Keywords: cultural services, provisioning services, regulating services, supporting services, belowground biodiversity, European forests

\section{INTRODUCTION}

In the Millennium Ecosystem Assessment (MEA, 2005) framework, ecosystem services (ES) represent the wide range of benefits ecosystems provide to people. Following this typology, the benefits here encompass goods, such as timber, food, and fuel ("Provisioning Services"), and ecosystems' abilities to purify air and water, to reduce flood risk, and to regulate pollination and carbon sequestration ("Regulating Services"). Soil formation, nutrient cycling, and primary production are necessary for the production of all other ecosystem services ("Supporting Services"). Less tangible services of ecosystems concern aesthetics, humans' "sense of home" and space for recreation ("Cultural Services"). Overall, ecosystem services are generated through ecosystem functions, which in turn are underpinned by biophysical structures and processes (de Groot et al., 2010; Haines-Young and Potschin, 2010), and driven by biodiversity (Balvanera et al., 2006). Alternatives to the MEA's framework of ecosystem services have been proposed, in particular from an economics' point of view (Boyd and Banzhaf, 2007; Fisher et al., 2009; TEEB, 2010; Maes et al., 2013), insisting on a distinction of so-called intermediate and final goods, as intermediate goods could be double-counted if they also contribute to the provision of final goods. Inspired by the cascade framework proposed by Haines-Young and Potschin (2010), Maes et al. (2013) proposed to present the services in three categories rather than four by regrouping "Regulating" and "Supporting Services" (MEA, 2005) together as "Regulating and maintenance services". The main issue here is to avoid double counting of services to humans, in particular when an economic valuation is the objective of the ES research. Even though one could be against the use of an anthropocentric definition of natural capital in an ES framework (Silvertown, 2015), the concept of ecosystem service clusters (de Bello et al., 2010) and the risk of double counting should be considered while using the MEA's typology.

Biodiversity is not considered as an ES per se, but its influence on the availability of ecosystem services has been emphasized, and biodiversity can be considered the basis for all ecosystem services. Biodiversity, as defined by the Parties to the Convention on Biological Diversity (CBD), is understood here as "the variability among living organisms from all sources including terrestrial, marine and other aquatic ecosystems and the ecological complexes of which they are part; this includes diversity within species, between species and of ecosystems"
(Mace et al., 2012). Biodiversity can be measured and described as species richness or richness-abundance measures, such as the Shannon index, or as functional diversity, i.e., the diversity of organism traits (Gaston, 2010; Violle et al., 2014), the latter establishing a direct link between the organisms' functional traits and ecosystem stability (Díaz et al., 2006; de Bello et al., 2010; Cardinale et al., 2012).

Soils are one of the biologically richest habitats on Earth, and per unit area the biodiversity in soils can be greater than aboveground biodiversity (Nielsen et al., 2015). The diversity of the soil biota ("belowground biodiversity") is essential for a range of key ecosystem functions and processes including decomposition, mineralization, and nutrient cycling, and their associated ecosystem services (MEA, 2005; Jeffery et al., 2010). Soil biota include a variety of life forms such as macroarthropods, earthworms, enchytraeids, collembola, nematodes, isopods, acari, bacteria, protozoa, archaea, and fungi (Briones, 2014). They also include plant roots and their exudates, forming the so-called rhizosphere (Hinsinger et al., 2009), attracting a variety of organisms and representing an important input to the soil food web. Soil biota mediate the supply of ecosystem services, in that they can suppress diseases, degrade pollutants, stimulate soil formation and water infiltration and through their effect on soil carbon dynamics contributing to climate regulation (Nielsen et al., 2015). In addition, ecosystem functioning depends on the tropic interactions between above- and belowground communities, biogeochemical cycling and plant-soil feedbacks (van der Heijden et al., 2008, 2015; Nielsen et al., 2015). However, our knowledge on the functioning of belowground communities is limited compared to our knowledge on aboveground communities, and even more so if we consider the relationship between belowground biodiversity and the supply of ecosystem services.

Many of the world's ecosystems are severely threatened through human pressures. Since 1700, human activities such as deforestation, urbanization, and agricultural practices have altered $50 \%$ and more of the terrestrial biosphere from mostly wild to mostly anthropogenic (Ellis et al., 2010). A continued loss of global biodiversity (Barnosky et al., 2011) and accelerating rates of environmental change threaten the functioning of ecosystems and provisioning of ecosystem, and maintaining ecosystem resilience is becoming increasingly important (Oliver et al., 2015). Globally, the decline in biodiversity threatens the humanity's life support system and human health (Díaz et al., 
2006; Rockström et al., 2009; Cardinale et al., 2012; Hanski et al., 2012; Hooper et al., 2012).

European forest ecosystems are no exception, as they have been, over the course of history, periodically subjected to degradation and overexploitation by humans. Most forests have been managed for specific markets and outputs with a strong control of tree species occurrence, are characterized by intensive plantations, often in monocultures and frequently with species planted beyond the limits of their natural range and/or on unsuitable soils (Spiecker, 2003; Johann et al., 2004). The consequences have been loss of biodiversity, soil degradation, yield decline, as well as increased risks (windthrow, fire, pathogen attack) through decreased resilience and resistance to stress (Spiecker, 2003; Johann et al., 2004). Temperate forests provide numerous important ecosystem services, such as biodiversity conservation, pollination, timber production, carbon sequestration, protection of water and soil resources, and recreation (Spiecker, 2003; Bastrup-Birk et al., 2016; FAO, 2016). They are also essential for climate-change adaptation and mitigation (FAO, 2016). While some relationships between tree species diversity, ecosystem functions (i.e., Dawud et al., 2016; Ratcliffe et al., 2017), and services (Gamfeldt et al., 2013; van der Plas et al., 2016) have been established, knowledge on the relation between the diversity of soil biota and forest ecosystem services remain scattered within the scientific literature, documenting the importance of specific taxa for individual functions, but not the global relation between soil biodiversity and ecosystem services.

Recent new technological advances have enabled researchers to collect extensive data on belowground taxonomic and functional diversity, and the question is whether the knowledge obtained on forest soil biodiversity is clearly related to the ecosystem services offered by forests and thereby useful in a policy context. In this review, we explore the relation between belowground biodiversity and the ecosystem services offered by European forests. Our general aim is to provide decision makers and stakeholders with clear research-based information on how biodiversity contributes to these services, the demand for them, the capacity of ecosystems to provide them, and the pressures impairing that capacity (Science for Environment Policy, 2015). Specifically, for the most important soil biota groups, the objectives of this review of the scientific literature were (1) to provide a synthesis of the relationships between soil biodiversity and forest ecosystem services, (2) to perform an indepth analysis of the nature of these relationships, and (3) to identify where knowledge is lacking.

\section{MATERIALS AND METHODS}

\section{Ecosystem Services and Biotic Groupings}

This work is the result of working group 1 "Linking belowground biodiversity to ecosystem function" of the European Cooperation in Science and Technology (COST) Action FP1305, a consortium of experts in different fields of belowground organisms, originating from 32 European countries and mobilizing around 100 experts at each meeting. In our approach, first, we used the framework of the Millennium Ecosystem Assessment (2005) to compose an initial list of ecosystem services to be evaluated from
TABLE 1 | Overview of ecosystem services investigated in our analysis for each of the four main groups.

\begin{tabular}{|c|c|}
\hline Provisioning services & Regulating services \\
\hline Food & Air quality regulation \\
\hline Fiber & Climate regulation \\
\hline Fuel & Water regulation \\
\hline Genetic resources & Erosion regulation \\
\hline $\begin{array}{l}\text { Biochemicals, natural medicines, and } \\
\text { pharmaceuticals }\end{array}$ & $\begin{array}{l}\text { Water purification and waste } \\
\text { treatment }\end{array}$ \\
\hline Ornamental resources & Disease regulation \\
\hline Fresh water & Pest regulation \\
\hline Platform & Pollination \\
\hline \multirow[t]{3}{*}{ Refuge } & Natural hazard regulation \\
\hline & Biotic regulation \\
\hline & Barrier effect of vegetation \\
\hline Cultural services & Supporting services \\
\hline Cultural diversity & Soil Formation \\
\hline Spiritual and religious values & Primary production \\
\hline $\begin{array}{l}\text { Knowledge systems (traditional and } \\
\text { formal) }\end{array}$ & Nutrient cycling \\
\hline Educational values & Water cycling \\
\hline Inspiration & Carbon cycling \\
\hline Aesthetic values & Supporting habitats \\
\hline \multicolumn{2}{|l|}{ Social relations } \\
\hline \multicolumn{2}{|l|}{ Sense of place } \\
\hline \multicolumn{2}{|l|}{ Cultural heritage values } \\
\hline \multicolumn{2}{|l|}{ Recreation and ecotourism } \\
\hline Health and well-being & \\
\hline
\end{tabular}

the belowground point of view in European forests. Accordingly, the ecosystem services were organized in four main groups: provisioning, regulating and cultural services that directly affect people, and supporting services, which are needed to maintain the other services (MEA, 2005). We expanded the number of ecosystem services identified and refined the description of each by consulting other core sources (Costanza et al., 1997; Jeffery et al., 2010; Maynard et al., 2010) and through discussions in expert workgroup sessions during the FP1305 COST Action meetings in Reading (November 2014), Krakow (March 2015) and Rome (November 2015). This permitted to compare the different functions, services and their definitions in the different sources, to list the relevant key words and to compose our own list of ecosystem services. The final list of ecosystem services investigated in our study is given in Table $\mathbf{1}$.

The COST FP1305 consortium consists of experts in different fields of belowground organisms, which for working group 1 (this study), represents 17 European countries and around 35 experts at each working group 1 meeting. According to the assumed relevance of different biotic groups in providing ecosystem services (expert opinions expressed in workgroup sessions) and the expertise in the consortium, a selection of biotic groups (and subgroups) was made for our analyses (Table 2). These biotic groups do not cover all possible organismal groups of forest 
TABLE 2 | Biotic groupings included in our analysis.

\begin{tabular}{llll}
\hline $\begin{array}{l}\text { Biotic } \\
\text { grouping }\end{array}$ & $\begin{array}{l}\text { subgrouping or } \\
\text { detail }\end{array}$ & $\begin{array}{l}\text { Biotic } \\
\text { grouping }\end{array}$ & $\begin{array}{l}\text { subgrouping or } \\
\text { detail }\end{array}$ \\
\hline Plants & roots & Soil fauna & $\begin{array}{l}\text { earthworms } \\
\text { enchytraeidae } \\
\text { collembola }\end{array}$ \\
Fungi & mycorrhizal fungi & & $\begin{array}{l}\text { acari } \\
\text { isopods }\end{array}$ \\
& saprotrophic fungi & & nematodes \\
& pathogenic fungi & & protozoa \\
Prokaryota & bacteria & algae \\
& archaea & Protists & \\
& & &
\end{tabular}

belowground diversity, but include the most important groups based on our expert opinion. Expertise in our group was strongest for plants, fungi and soil fauna, but prokaryotes and protists were also included in our approach.

\section{Key Word Searches}

We performed a literature survey using main searches based on standardized sets of three to four key-words for each of the combinations of ecosystem services and biotic groupings (Electronic Supplementary Material 1) in the "Web of Science" (Clarivate Analytics, Philadelphia, USA). The datasets obtained included references until December 2015 to June 2016 (date at which the last survey was performed) and newer references were not sought for afterwards. In total, these queries represent 37 ecosystem services (Table 1) against 14 biotic subgroupings (Table 2). The output of these queries was saved in text files and shared for subsequent inspection by the panel of experts. First, a screening was applied to the list of total hits (hereafter termed "studies" or "sources") based on general exclusion/inclusion guidelines, using titles, and abstracts of the references encountered for each combination of key words. We used the following guidelines for inclusion of potentially useful references for the next steps of evaluation: the source should (1) refer to an European ecosystem; (2) relate to forested ecosystems; (3) include or focus solely on belowground functions, processes and selected biotic groupings, and (4) respect the direction of the relationships, i.e., the diversity of any specific biotic grouping must affect an ecosystem service and not the other way around. The a priori exclusion of references from the list of studies was based on the reference not fulfilling any of the above conditions or being clearly out of scope (for instance the key-word "supporting" includes very unspecific results such as "supporting our hypothesis"). The process leading to the list of "potentially useful studies" is presented in Figure $\mathbf{1 .}$

\section{Paper Abstracts Evaluation and In-Depth Examination of the Obtained References}

Experts on specific biotic groups went through the files containing all of the studies and selected potentially useful studies to check the quality of the references found. Based on the judgement of the abstracts, they accessed potentially useful references for inspection of the full paper content. The effects of biodiversity on a given service for a given biotic grouping were assessed and recorded in text files with annotations to enable synthetic analyses. First, the experts evaluated whether the study reported on a change in biodiversity of a specific biotic group or not (studies only reporting on presence of a given species or on a density gradient of only one species were thus discarded). Secondly, the ecosystem service considered should show a response to this change in biodiversity (positive, negative, or neutral). This full paper screening was carried out per biotic group. This permitted the refinement of the selection (discarding irrelevant studies from the list of potentially useful hits). Based on expert opinions, some studies appeared valuable for a service or biotic group other than originally suggested and were therefore transferred to the appropriate biotic group and service combination. For instance, a reference encountered for "roots" and "Provisioning Services" irrelevant for this combination could be relevant for "roots" and "Supporting Services" and therefore was transferred to the latter service group. This occurred in a minority of cases. Finally, specifically for Cultural Services, an additional set of key words was deployed for the largest biotic groupings of plants, fungi, and soil fauna using Google Scholar. This was combined with a snowball approach (i.e., tracking down the cited references within a few source papers) for Cultural Services giving no or few studies in the main queries (Electronic Supplementary Material 2).

\section{Step-by-Step Synthesis of the Query Results}

The expert search findings per biotic grouping (number of potentially useful studies, and final number of relevant studies used) were presented and incremented during the COST meetings [i.e., in Sofia (April 2016), Prague (October 2016) and Vienna (March 2017)] and discussed at the ecosystem services grouping level (i.e., Provisioning, Regulating, Cultural, and Supporting Services). Then, we accounted for the total number of used studies (Figure 1) and the number of studies showing a positive, negative, or neutral relationship between biodiversity of a biotic grouping and a given ecosystem service. Summary data sets were subjected to further synthesis by panels of experts for each ecosystem services group.

\section{Sensitivity Analysis}

With the aims of (1) evaluating the occurrence of doublecounted references and of (2) assessing the bias of studies going unnoticed due to the use of a too narrow set of key words in our general literature survey, we performed a sensitivity analysis to our data set. First, for the references found in our survey, we compared which references occurred for more than one ecosystem service category and assessed whether these could be considered as overlapping (double counted as they were listed in the same ecosystem service cluster, e.g., carbon cycling and climate regulation) or not. Secondly, for the services related to "food", "fiber", "fuel" and "educational values", a broader set of key-words was used for a comparative literature survey. The extended key word sets used were for food "(food OR crop* OR harvest OR productivity OR production OR yield OR edible)”, for fiber "(fiber OR timber OR wood OR cellulose)", for fuel "(fuel 


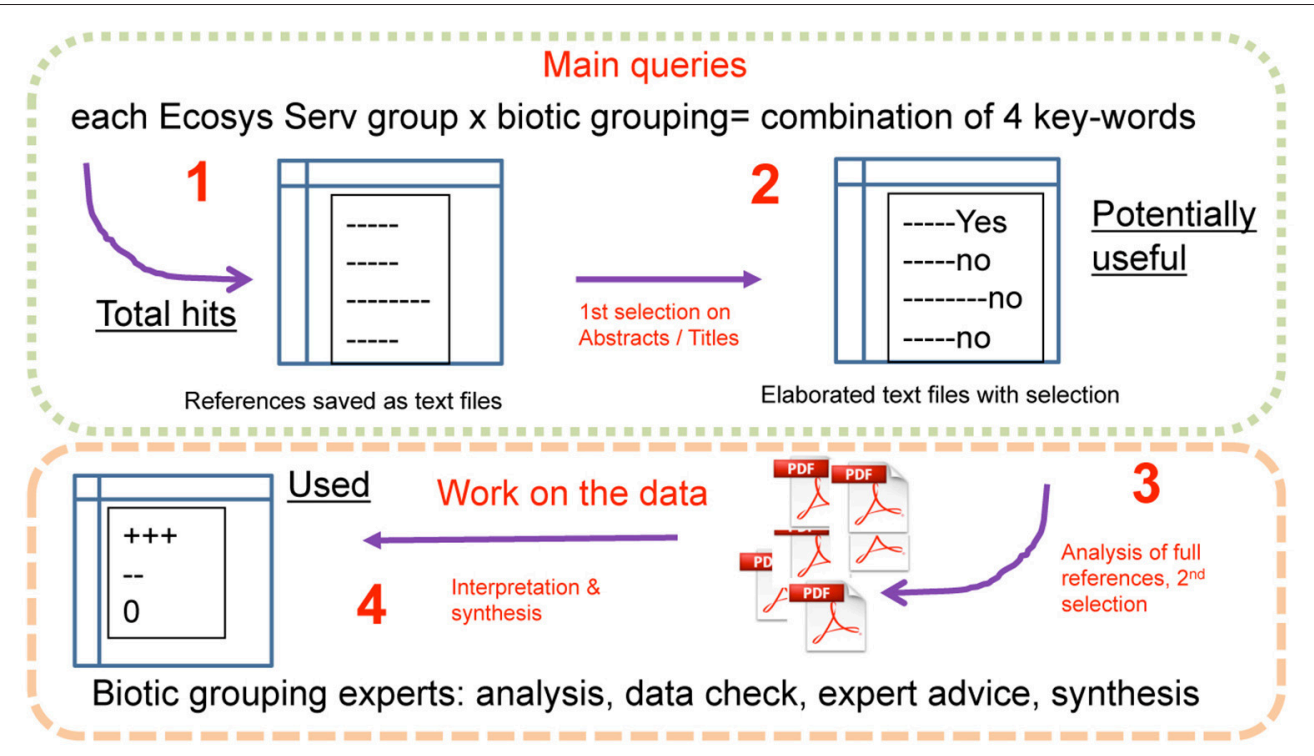

FIGURE 1 | Organization of the work.

OR wood OR energy)", and for educational values "(education OR school OR learn* OR teach* OR training)". The results of both assessments were compared with the main dataset.

\section{RESULTS}

\section{Main Queries Per Ecosystem Service and Biotic Group}

The main queries (Electronic Supplementary Material 1) resulted in 10623 studies with an average 23 studies $(\mathrm{SE}=51$ hits) for each of the 518 queries (37 ecosystem services, 14 biotic subgroupings) and varied from zero (no study) to 503 studies (Figure 1, step 1). The four main ecosystem service classes had comparable numbers of total studies and these ranged from the lowest value of 2,353 studies for Cultural Services to the highest value of 2,821 studies for Supporting Services. The relative frequency of the total studies for the biotic sub-grouping differed between ecosystem service (Figure 2A), with stronger variation between ecosystem service groups for pathogens, bacteria, and nematodes relative to their share of the total studies. Most total studies corresponded to roots, bacteria, nematodes and to a lesser extent pathogens and protozoa. Overall, studies related to roots made up 16-19\% of the total studies, mycorrhizae $7-12 \%$, saprotrophs $3-4 \%$, pathogens $3-15 \%$, bacteria $9-28 \%$, archaea $3-8 \%$, earthworms 2-5\%, enchytraeidae $0-3 \%$, collembola $1-3 \%$, acari $2-5 \%$, isopods $0-1 \%$, nematodes $2-27 \%$, protozoa $2-10 \%$, and algae 4-7\% (Figure 2A; for more details see Electronic Supplementary Material 3). The distribution of total studies per main ecosystem services group showed relatively similar patterns for Provisioning and Supporting Services relative to the five main biotic groupings, whereas Cultural Services showed less studies for soil fauna and protists and Regulating Services higher numbers for soil fauna (Figure 3A).

\section{Abstract Evaluation and Expert Inputs}

Based on the inspection of the 10,623 abstracts, we explored using our four main guidelines of exclusion/inclusion whether the belowground diversity within each biotic grouping was associated with given individual ecosystem services in forested ecosystems within Europe. For instance, Balvanera et al. (2014) demonstrated how biodiversity can affect an ecosystem service: 'an increased species richness of plants and algae reduces $\mathrm{N}$ concentrations in the water, thus, this is a clear positive effect on the Regulating Service "water purification". After abstract inspection, only 609 out of the 10,623 initial studies were considered potentially useful studies (Figure 1, step 2) with 161 for Provisioning, 142 for Regulating, 247 for Supporting Services, and only 59 for Cultural Services (Figure 3B). The relative frequency of the potentially useful studies also changed relative to the initial results obtained in the key word queries: the proportion of some biotic subgroupings (such as roots) decreased whereas the proportion for others (such as mycorrhizal, saprotrophic, and pathogenic fungi) increased (Figure 2B) or in the case of bacteria remained similar (Figure 2B; see Electronic Supplementary Material 3 for a detailed overview). Overall, the contribution of fungi to the potentially useful studies was $24-73 \%$, comparable to its share of the total number of studies (Figure 3B). Based on the total number of studies, plant roots contributed less than expected (only 3-6\%). The contributions to the overall pool of potentially useful studies of the biotic groupings prokaryota, soil fauna and protists varied (representing 14-23, 10-41, and 0-17\%, respectively; Figure 3B). Cultural Services were less well-represented, with the exception of fungi (Figure 3B). Due to the difficulty in finding references related to Cultural Services, specific queries were run for this group of services (Electronic Supplementary Material 2). Expert evaluations of the full references and the work on the data collected (Figure 1, steps three and four), along with 
A

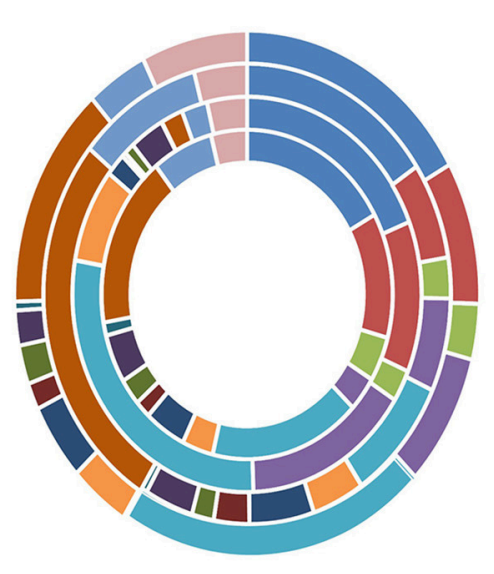

B

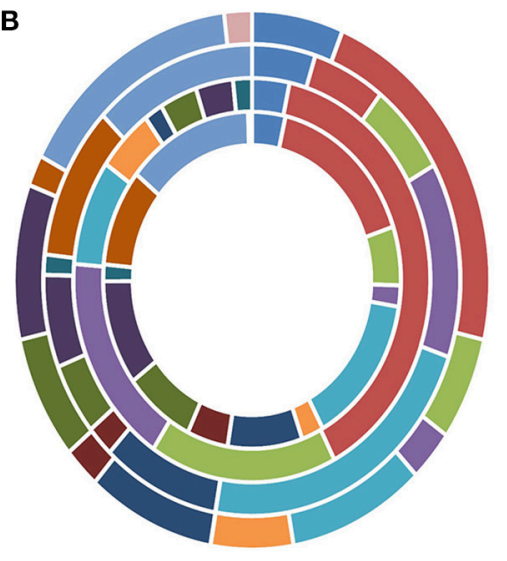
- roots
- mycorrhizae
saprotrophs
archaea
- earthworms
enchytraeidae
pathogens
- bacteria
- isopods
- nematodes
protozoa
n collembola
- acari

FIGURE 2 | Percentage distribution of total studies (A) and potentially useful studies (B) per biotic subgrouping occurring for the four ecosystem service groups (from outside to inside: Provisioning services, Regulating services, Cultural services, and Supporting services).
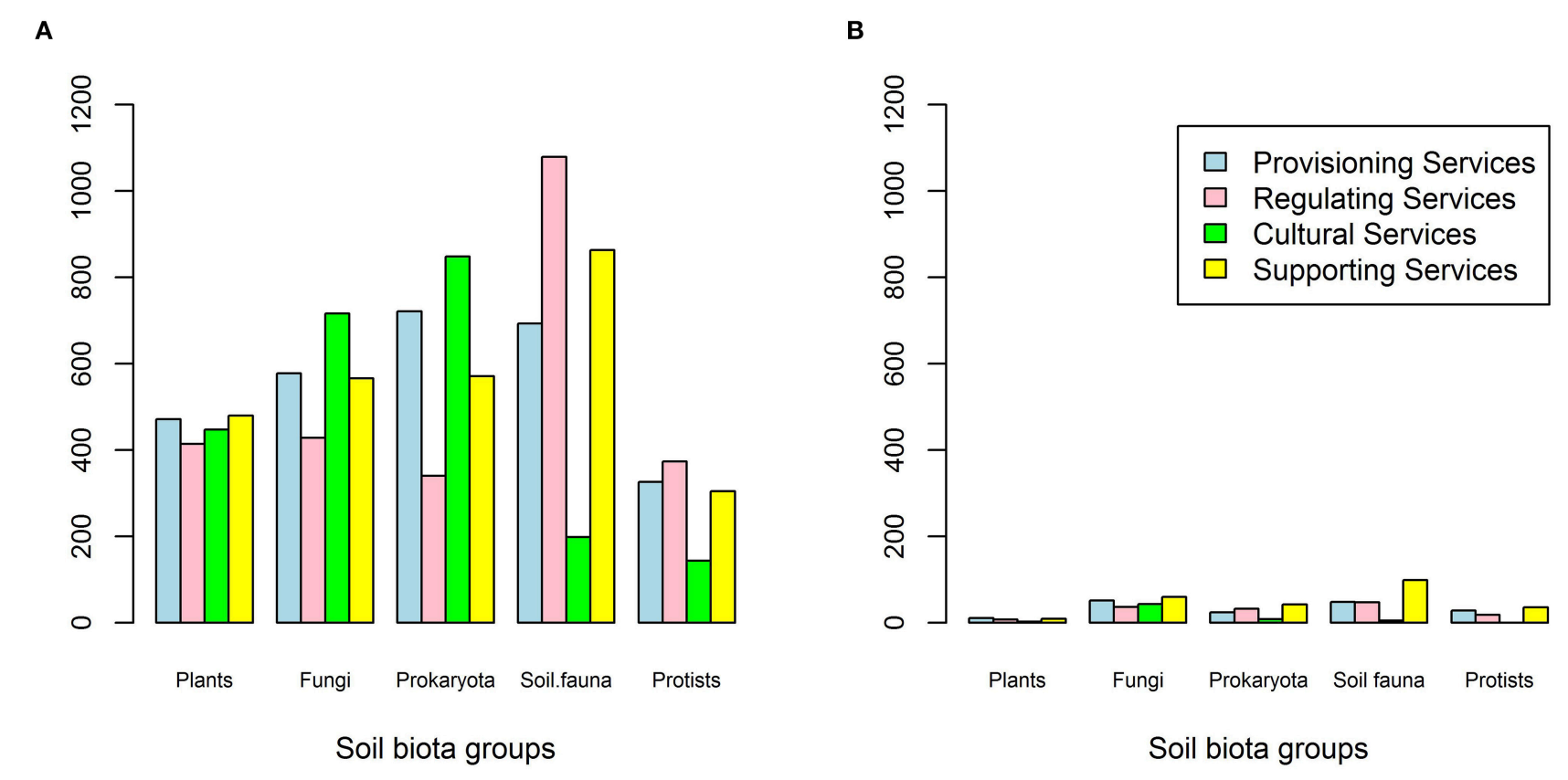

FIGURE 3 | Distribution of total studies (A) and potentially useful studies (B) per main soil biotic grouping and ecosystem service group.

the inclusion of references found through other queries and the input from expert advice as well as additional queries for Cultural Services (Electronic Supplementary Material 2), led to a final number of 574 references being used (Table 3). These references were for $1 \%$ older than 1990 , for $13 \%$ were published in the 1990 s, for $29 \%$ in the 2000 s, and for $57 \%$ in the 2010s.

\section{Soil Biodiversity and Ecosystem Services}

In a first step, the relationships between belowground biodiversity and ecosystem services were evaluated by considering the direction of the relationship for all 574 studies obtained from the 518 combinations of ecosystem services and biotic sub-groupings (Electronic Supplementary Material 4). The numbers of studies showing a positive, negative or neutral 
TABLE 3 | Numbers of studies finally used per ecosystem service group, the observed relationships occurring within these studies (positive, neutral, or negative), the number of combinations between ecosystem services and biotic subgroupings ("cell") and the dominant type of relationship for each such combination (based on one value per cell).

\begin{tabular}{|c|c|c|c|c|c|c|c|c|c|c|}
\hline \multirow[t]{2}{*}{ Ecosystem service group } & \multirow{2}{*}{$\begin{array}{l}\text { Number } \\
\text { Studies }\end{array}$} & \multicolumn{3}{|c|}{ Relationships ${ }^{a}$} & \multirow[t]{2}{*}{ Number ${ }^{b}$ cells } & \multirow[b]{2}{*}{$N^{c}$} & \multicolumn{4}{|c|}{ Dominant trend } \\
\hline & & + & $\mathbf{n}$ & - & & & + & $\mathbf{n}$ & - & All \\
\hline Provisioning services & 60 & 42 & 15 & 3 & 126 & 97 & 25 & 1 & 3 & $\nearrow$ \\
\hline Regulating services & 26 & 15 & 7 & 4 & 154 & 141 & 8 & 4 & 1 & $\nearrow$ \\
\hline Cultural services & 362 & 311 & 14 & 37 & 154 & 92 & 57 & 3 & 2 & $\nearrow$ \\
\hline Supporting services & 126 & 96 & 27 & 3 & 84 & 44 & 35 & 3 & 2 & $\nearrow$ \\
\hline All services & 574 & 464 & 63 & 47 & 518 & 374 & 125 & 11 & 8 & $\nearrow$ \\
\hline
\end{tabular}

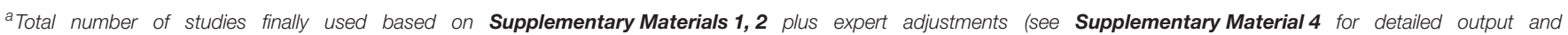
Supplementary Material 5 for the complete list of sources used).

${ }^{b}$ Total number of combinations between ecosystem services (Table 1) and biotic subgroupings (Table 2).

${ }^{c} N D$, no data were found for this number of combinations between Ecosystem services and biotic subgroupings.

relationship are summarized in Table 3 . The large majority (464 studies) showed a positive relationship, with comparable numbers (63 and 47) for neutral and negative relationships (Table 3). In a second step, the dominant trends for each of the 518 potential relationships were listed, using color and size of the arrows to highlight the number of studies underlying each relationship (Figure 4). From these 518 combinations a relationship between the diversity in a given biotic group and ecosystem service was recorded for 144 (28\%), whereas for 374 (72\%) no data could be found (Figure 4). The percentage of cases with a relationship varied strongly between main ecosystem services with 23\% for Provisioning Services, $8 \%$ for Regulating Services, $40 \%$ for Cultural Services, and $48 \%$ for Supporting Services. In $71 \%$ of the combinations of biotic groups and a given ecosystem service our interpretation of the relationship was based on only 1-3 studies, $14.5 \%$ were based on $4-7$ studies and $14.5 \%$ had 8 or more studies. The majority of the relationships were positive ( $81 \%$ of the studies, $87 \%$ of combinations of biotic group and ecosystem service), with lower proportions being neutral ( $11 \%$ of studies, $8 \%$ of combinations) or negative ( 8 and $5 \%$, respectively).

In the case of Provisioning Services, 25 (20\%) of the relationships were positive (Figure 4). These relationships, with one exception, were each based on only one to three studies. Three negative relationships were recorded (2\%), and one relationship was evaluated as neutral (1\%), but the large majority of possible relationships between services and biotic groups yielded no sources (no data available). For Regulating Services, eight positive relationships were found ( $5 \%$ of all), one negative (1\%), four neutral (3\%), and 141 of the combinations had no data to evaluate whether there was a relationship or not (91\%). Again, the relationships were based in majority on only a few studies (1-3 studies). Comparatively, Cultural Services featured many more relationships: 57 (37\%) were positive, two (1\%) negative and three (2\%) were neutral. For the remaining 92 combinations (60\%) no data were found to evaluate the type of relationship (Table 3). For the majority of combinations where relationships for Cultural Services were found, the results were based usually on 4-7 or even more than seven studies (Figure 4). For the Supporting Services, 35 positive relationships were found (42\%), three neutral (4\%), two negative (2\%) and $44(52 \%)$ had no data to investigate relationships. The right part of Table 3 regroups the descriptive sum values for the 518 dominant relationships: a large majority of the investigated relationships (374 out of 518) could not be assessed due to lack of data, 125 of the relationships were positive, 11 of the relationships were neutral and eight were negative. Finally, the overall picture of the dominant relationships between the four main ecosystem service groups and five main biotic groups showed a majority of positive relationships (Figure 5).

\section{Sensitivity Analysis}

The use of an extended set of key words for the ecosystem services "food", "fiber", "fuel" and "educational values", resulted in 2.7-10.6 times more references than in the original key word searches (Table 4). Overall, the broader set of key words yielded 7.3 times more references (6,354 compared to 871 references) for our set of comparisons ( 4 services, 14 soil biota categories). Inspection of these 6,354 references (title + abstract), brought the number down considerably ( 83 for the extended key-word search, against 67 in the original one). The final inspection of the entire papers resulted in the occurrence of three new papers that we failed to find in our original queries. Two occurred for plant roots (one neutral for fiber provisioning, one positive for educational values) and one appeared in the queries but more appropriate for another service (a positive relationship for fungi and nutrient cycling). The inspection of sources appearing in more than one ecosystem service category-in view of evaluating the degree to which double counting of sources occurred in our work-permitted to find 11 studies. Four of these studies showed no overlap (i.e., when used for one ES category, this was completely different from their use in another ES category, meaning that they did not belong to a same cluster of ES), three showed partial overlap and four showed overlap. This concerned the clusters climate regulation vs. C cycling (3 studies), water cycling vs. water/erosion regulation (2 studies), and fiber/fuel provision vs. nutrient cycling (2 studies). Irrespective of how much these sources in their ecosystem service provision actually overlap the seven studies concern five cases for overlap between regulating and supporting ES and two cases between supporting and provisioning ES. 


Biotic sub-groupings
roots
mycorrhizae
saprotrophs
pathogens
bacteria
archaea
earthworms
enchytraeidae
collembola
acari
isopods
nematodes
protozoa
algae

Provisioning Services

Regulating Services

Cultural Services

Supporting Services
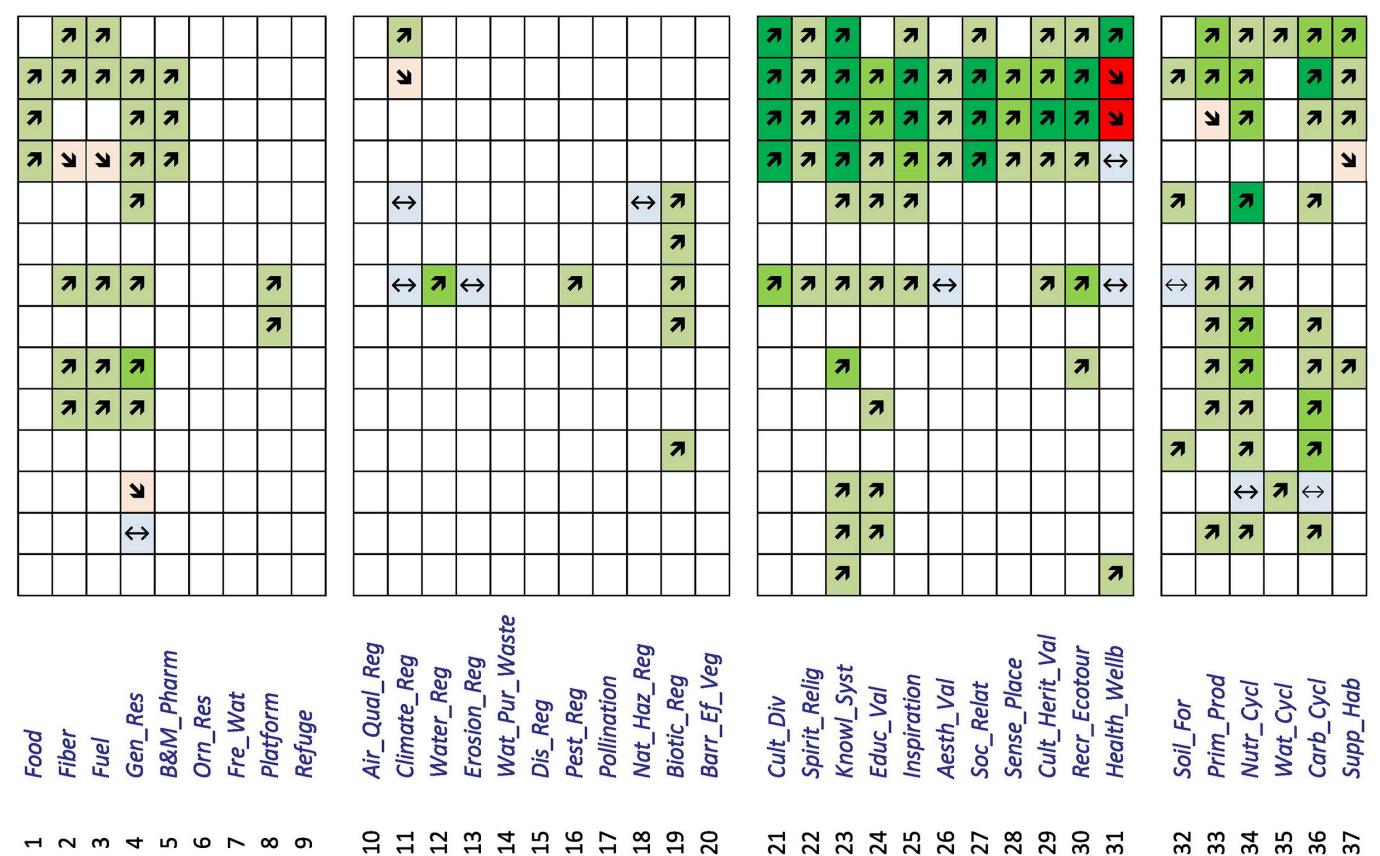

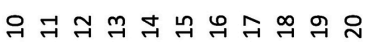

ㄱํำ

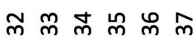

FIGURE 4 | Relationships between belowground biodiversity of different biotic subgroupings and ecosystem services. Green colors and arrows pointing upward indicate positive relationships (the lightest color and finest arrow represent 1-3 studies, the intermediate color, and size 4-7 studies and the darkest color and thickest arrow 8 studies or more). Likewise, red colors (and arrows pointing downward) indicate 3 levels of studies (1-3, 4-7, and 8 or more) for a negative relationship. Blue colors (and level signs) indicate a neutral result. Empty cells indicate no studies were found to evaluate the combination of this biotic subgrouping and the corresponding ecosystem service.

\begin{tabular}{|c|c|c|c|c|c|}
\hline & $\begin{array}{l}\stackrel{\sim}{ \pm} \\
\frac{\subsetneq}{\sigma} \\
\frac{\sigma}{a}\end{array}$ & $\begin{array}{l}\overline{50} \\
\sqsubseteq \\
\doteq \\
\perp\end{array}$ & $\begin{array}{l}\text { ic gr } \\
\frac{0}{+} \\
\frac{0}{2} \\
\frac{\pi}{0} \\
\frac{0}{0} \\
\frac{1}{0}\end{array}$ & 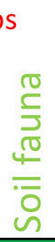 & 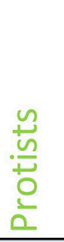 \\
\hline \multirow{4}{*}{$\begin{array}{l}\text { Provisioning Services } \\
\text { Regulating Services } \\
\text { Cultural Services } \\
\text { Supporting Services }\end{array}$} & $\pi$ & $\pi$ & $\lambda$ & $\pi$ & $\leftrightarrow$ \\
\hline & $\leftrightarrow$ & $\searrow$ & $\pi$ & $\pi$ & ND \\
\hline & $\pi$ & $\pi$ & $\lambda$ & $\lambda$ & $\lambda$ \\
\hline & $\pi$ & $\pi$ & $\pi$ & $\pi$ & $\pi$ \\
\hline \multicolumn{6}{|c|}{$\begin{array}{l}\text { FIGURE } 5 \text { I Overall picture of the relationships between belowground } \\
\text { biodiversity of different biotic groups and ecosystem services. Green, red, and } \\
\text { blue colors indicate positive, negative and neutral relationships, respectively. } \\
\text { The intensity of the color (and size of the arrows) indicate the number of } \\
\text { studies underlying the dominant relationship with three levels: } 1-3,4-7 \text {, and } 8 \\
\text { or more sources. }\end{array}$} \\
\hline
\end{tabular}

\section{DISCUSSION}

\section{Belowground Biodiversity in European Forests Is Positively Related to the Production of Many Ecosystem Services}

The role of biodiversity in actual and future provision of ecosystem services has been pointed out (Cardinale et al., 2012;
Mace et al., 2012; Balvanera et al., 2014), and managers should consider biodiversity seriously, as inappropriate management of ecosystems could jeopardize the maintenance of its functions and services (Díaz et al., 2018). Soil biodiversity was shown to be a main driver of ecosystem stability (Yang et al., 2019) and adaptation of forestry practices and tree species composition was proposed to be able to sustain the supply of services under conditions of climate change (Luyssaert et al., 2018). Many ecosystem services have been taken for granted and considered infinite. It has become now clear that the degradation of ecosystems (Ellis et al., 2010), occurring worldwide, is also diminishing the services which they can provide. At the European level, soil biodiversity is threatened in particular in areas of high population density along with those having an intense agricultural activity (Jeffery et al., 2010). The use of ecosystem services as a concept permits to study and compare the different functions and services of ecosystems along with an assessment of how this is associated with other key aspects such as biodiversity and how this could be affected by environmental change. It further helps in raising public awareness and gives input for decision makers (Science for Environment Policy, 2015).

Here, in our investigation of the relationships between soil biodiversity and ecosystem services in European forests, we collected data from published studies with the objectives of synthesizing the existing knowledge, exploring the nature of the relationships, and defining knowledge gaps. Overall, we 
found 574 studies for the 518 combinations of biotic groups and ecosystem services, i.e., on average a bit more than one study per combination, even though some studies contributed to several relationships. We detected that $92 \%$ of our combinations of belowground biodiversity of a given biota group and one individual ecosystem service were not covered by data or were only addressed by very few studies. For most of the investigated combinations, knowledge is thus lacking. Of the remaining $8 \%$ of well-assessed links between soil biota diversity and ecosystem services, the great majority of relationships was mainly positive. However, for some soil biota groups contrasting relationships were detected, suggesting an ambiguous nature of these links, likely being driven by competition between soil biota groups, driven by influence of the environmental context of studies, or related to the antagonistic nature of some services.

Specifically, for Provisioning services, an increasing diversity of soil biota was associated with the supply of provisioning services for most biotic sub-groups. A few neutral and negative cases were also found and for some, e.g., algae, no direct evidence could be found. In the case of Regulating Services, an increase in belowground diversity appeared only for a small number of potential relationships and in two-third of all cases this was associated positively with ecosystem services; the rest showing mostly a neutral or in one case a negative relationship. Almost all biotic groups contributed to the provision of Cultural Services, but the positive effect of higher biodiversity (in the sense of number of species) was not straightforward. Within the biotic groups, the importance of biodiversity depended on a complex of natural and cultural phenomena such as species occurrence in the area, folk recognition of the species or tradition of use. Here, we did not find any published evidence for archaea and enchytraeidae as direct providers of any cultural benefits. Supporting Services of belowground diversity are reported for most soil fauna and fungi, and less so for the smallest taxa (prokaryota, protists), with a surprisingly small role for plant roots. The majority of these relationships are positive with only a few studies showing neutral or negative relationships. In the subsequent sections, we first illustrate the specific character of the relationships between belowground biodiversity and ecosystem services across all main service categories for the main biotic groups, discuss the implications of the choice of using the MEA framework in our study of ecosystem services and then present a few general considerations of our work.

\section{The Specific Relationships Between Belowground Biodiversity and Ecosystem Services in European Forests Plant Roots}

Plant roots are the main interface between aboveground and belowground biota, influence their environment through uptake of nutrients and water, and in turn supply the soil with carbon and exudates. The environment in the close vicinity of the most active exchange parts of the root system, the socalled rhizosphere, harbors a large diversity of microorganisms (Hinsinger et al., 2009). A mixed species forests with a higher aboveground diversity of species would support higher root diversity belowground, which should provide better spatial and depth root coverage due to different fine and coarse root distributions of different tree species. In such a case, root systems could be competing for the same resources, optimize the occupation of space and thus resource acquisition or feature vertical root segregation to avoid competition. With this respect, tree diversity in several cases led to a positive species interaction with higher growth, i.e., higher provisioning services for fiber or fuel (Pretzsch et al., 2013; Jucker et al., 2014; Pretzsch and Zenner, 2017). A positive effect on water cycling through a higher diversity of tree species and in turn plant roots was found by Grossiord et al. (2014), where in specific species mixtures Fagus sylvatica extracted water from progressively deeper soil layers. Dawud et al. (2016) reported higher root biomass in deeper soil layers with increasing tree species diversity and this was associated with higher subsoil $\mathrm{C}$ stocks. In the case of biotic disturbances, the presence of more resistant or resilient species in mixtures compared to monocultures with only susceptible or less resilient species can prevent damage or lessen the reduction in ecosystem function (Bauhus et al., 2017; Pretzsch and Zenner, 2017).

Differences in root distributions, root morphology and root architecture in mixed forest systems, are expected to positively affect soil formation through its influence on decomposing root systems, water purification through a decelerating effect on water flows and hydrological cycles between the soil and plants (Christen and Dalgaard, 2013). Roots play an important role in reducing runoff and soil loss. This has been recently reviewed by Liu et al. (2018). Roots were shown to have a particular role (compared to aboveground vegetation) in forests (as compared to grassland). The diversity of tree roots positively affected supporting habitats for fungi (Summerbell, 2005; Danielsen et al., 2012), collembolans (Rossetti et al., 2015), mites and microbes (Nielsen et al., 2012) and through decaying root systems for insects and polypores (Kolström and Lumatjarvi, 1999). Plant root biodiversity contributed positively to most of Cultural Services through the use of roots of edible or medicinal plants. Belowground parts of forest plants are still used in European countries, thus contributing to cultural diversity and heritage as a part of local tradition (Leporatti and Ivancheva, 2003; Šarič-Kundalič et al., 2010; Turner et al., 2011; Stryamets et al., 2015). A number of publications dealing with tradition of plant gathering also note their medicinal properties, reflecting their positive benefits for health and well-being and value of traditional knowledge and spiritual rituals (Ivancheva and Stantcheva, 2000; Vogl et al., 2013). Stryamets et al. (2015) show tradition of wild plant gathering as having positive influence on social relations, recreation and general health. Trestrail (2000) and Carter (2003) provide examples how roots and use of poisons (including those derived from plant roots) are depicted in artwork and fiction literature.

A number of studies reported on the positive contribution of a higher diversity of tree plant roots on nutrient cycling, carbon cycling, and primary production (Vilà et al., 2004; Guckland et al., 2009; Meinen et al., 2009a,b,c; Gundale et al., 2010; Lang and Polle, 2011; Lei et al., 2012; Jacob et al., 2014; Schleuß et al., 2014; Domisch et al., 2015; Dawud et al., 2016). Most of 


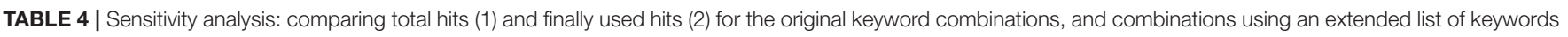
(_ext) for four selected services (italic values are the sum values of the four services).

\begin{tabular}{|c|c|c|c|c|c|c|c|c|c|c|}
\hline & \multicolumn{2}{|c|}{ Plants } & \multicolumn{2}{|c|}{ Fungi } & \multicolumn{2}{|c|}{ Prokaryota } & \multicolumn{2}{|c|}{ Soil Fauna } & \multicolumn{2}{|c|}{ Protists } \\
\hline & (1) & (2) & (1) & (2) & (1) & (2) & (1) & (2) & (1) & (2) \\
\hline food & 114 & 0 & 213 & 3 & 235 & 0 & 33 & 0 & 99 & 0 \\
\hline food_ext & 1,058 & 0 & 1,229 & 3 & 1,004 & 0 & 75 & 0 & 212 & 0 \\
\hline fiber & 21 & 3 & 12 & 4 & 14 & 0 & 1 & 4 & 1 & 0 \\
\hline fiber_ext & 283 & 4 & 682 & 4 & 238 & 0 & 21 & 4 & 34 & 0 \\
\hline fuel & 26 & 3 & 36 & 4 & 44 & 0 & 4 & 4 & 11 & 0 \\
\hline fuel_ext & 314 & 3 & 668 & 4 & 307 & 0 & 24 & 4 & 55 & 0 \\
\hline education & 1 & 0 & 0 & 10 & 0 & 1 & 4 & 4 & 2 & 1 \\
\hline education_ext & 57 & 1 & 44 & 10 & 39 & 1 & 2 & 4 & 8 & 1 \\
\hline total & 162 & 6 & 261 & 21 & 293 & 1 & 42 & 12 & 113 & 1 \\
\hline total_ext & 1,712 & 8 & 2,623 & 21 & 1,588 & 1 & 122 & 12 & 309 & 1 \\
\hline difference & 1,550 & 2 & 2,362 & 0 & 1,295 & 0 & 80 & 0 & 196 & 0 \\
\hline diff\% & 1,057 & 133.3 & 1,005 & 100 & 542 & 100 & 291 & 100 & 274 & 100 \\
\hline times & 10.6 & 1.33 & 10.1 & 1 & 5.42 & 1 & 2.91 & 1 & 2.74 & 1 \\
\hline
\end{tabular}

food, food_ext=food OR crop* OR harvest OR productivity OR production OR yield OR edible. fiber, fiber_ext $=$ fiber OR timber OR wood OR cellulose.

fuel, fuel_ext = fuel OR wood OR energy.

education, education_ext=education OR school OR learn* OR teach* OR training.

these relationships were described as weakly positive or neutral in gradients of tree plant diversity from one to five species and it seems premature to draw firm conclusions on a positive effect of tree plant roots. Notably, one group of researchers reported a positive effect on primary production and carbon cycling in one study (Meinen et al., 2009a) and twice a rather neutral effect (Meinen et al., 2009b,c). Schleuß et al. (2014) showed higher carbon concentrations in soils under species diverse stands compared to monocultures and suggested that differences in fine root biomass, fine root turnover, speciesspecific rhizosphere effects along with differences in leaf litter decomposition could explain this. Metcalfe et al. (2011) suggested that plant community composition, rather than diversity exerts usually the dominant control on soil carbon efflux in natural systems. In their review, Vesterdal et al. (2013) argued that species identity (of one species in the mixtures) could welldrive the observed diversity effects. Overall, the role of roots in the diversity-ecosystem functions seems to be underscored in our study, presumably because most studies assessing ecosystem functions of plant roots investigate only one tree species.

\section{Fungi}

A higher diversity of fungi was suggested to positively influence soil formation and primary production through direct effects on host physiology, nutrient benefits for plants and development of mycelium and through indirect effects on plant soil microbial community composition and functioning (Lavelle et al., 1997; Rillig, 2004; Hoeksema et al., 2010) and as such contributes to many ecosystem processes as regulators of ecosystem processes (Heilmann-Clausen et al., 2015). There are indications that in the case of a higher diversity of fungi, there is a benefit due to an increase of the productivity of trees, and thus, the supply of the services "fiber" and "fuel", but the effects of fungal diversity on primary production varied according to the set-up. For instance, Jonsson et al. (2001) showed that in a fungal diversity gradient from one to eight species, the effects on primary production were neutral to positive under conditions of low fertility substrate and neutral to negative under conditions of high fertility substrate for respectively Betula pendula and Pinus sylvestris. Similarly, in the study by Ducic et al. (2009), the interaction with soil properties and host tree variety exerted a stronger influence on production and nutrient use efficiency than fungal diversity on the roots. With respect to pathogenic fungi, Aponte et al. (2013) pointed out that most reported plant-soil feedback effects mediated by soil pathogenic fungi on the production of fiber and fuel are negative. However, Gómez-Aparicio et al. (2012) found no evidence of a plant-soil feedback effects via soil pathogens in their analysis of the spatial patterns of soil pathogens in mixed Quercus forests.

Through the production of fruiting bodies, a diverse fungal microflora directly influences the supply of "food" and "biochemicals, natural medicines, and pharmaceuticals" (Heilmann-Clausen et al., 2015). Mushrooms of over 1100 fungal species are used as source of food or traditional medicine in more than 80 countries (Boa, 2004). This includes all three categories of fungi: mycorrhizal, saprotrophic, as well as pathogenic fungi. Bonet et al. (2008) showed mushroom carpophore production to be positively related to belowground fungal diversity in Pinus sylvestris forests in the Pyrenees, while the highest diversity and production did not occur simultaneously in the study by Hernández-Rodríguez et al. (2015) in a Mediterranean scrub forest subjected to clearing and fire. Both nutrient and carbon cycling benefited from higher fungal diversity. Fungimycorrhizal, saprotrophic, and pathogenic-were mentioned as providers of local tradition, linguistic diversity and folklore in 
many European countries (e.g., Wasson and Wasson, 1957; Spooner and Læssøe, 1994; Härkönen, 1998; Gyozo, 2010; YaminPasternak, 2011). Positive effects of fungi on spiritual and religious values through the beliefs and mythology connected to mushrooms and mushroom picking are shown by Trinkauske (2008) and (Dugan, 2008a,b). Also, (Dugan, 2008a,b) and YaminPasternak (2008) indicate significance of fungi for heritage values: traditional cuisine, depiction in ancient texts and artifacts. Numerous references deal with fungi as objects of inspiration and two of them (Kiernan, 2010; Rutter, 2010) also mention aesthetic values of fungi.

Fungal diversity positively affects the general level of knowledge on fungi and use of fungi, both traditional (mainly pertaining uses of fungi and mushroom picking) and formal (use of fungi in archaeology, paleoecology, forensics, ethnology, soil and evolutionary sciences, environmental monitoring). Fungi are important for teaching students and more widely for environmental education (Ramesh, 2016; Halme et al., 2017). A neutral effect of fungi for knowledge systems was indicated: use of fungi for environmental monitoring (Rantalainen et al., 2008; Egli, 2011) and their effectiveness as medicines (Money, 2016). Fungi contributed to the "sense of place", as mushroom picking is an important part of life and is associated with "sense of home", mainly for Eastern Europeans (Wasson and Wasson, 1957; Härkönen, 1998; Yamin-Pasternak, 2011). Fungi and their gathering contribute positively to various aspects and levels of social relations: family and community ties, knowledge and tradition transfer, and socio-economic impact (Trinkauske, 2008; Luczaj and Nieroda, 2011; Yamin-Pasternak, 2011; GaribayOrijel et al., 2012). Mushroom gathering (mostly mycorrhizal and saprotrophic fungi) is a popular recreation form in many countries (e.g., Stryamets et al., 2015; Sisak et al., 2016). In addition, mycorrhizal fungi are used to monitor the condition of recreational forests (e.g., Barrico et al., 2012). Positive impacts on health and well-being were shown through fungi as sources of bioactive compounds (e.g., Heleno et al., 2010) and through positive effects of mushroom gathering as a physical activity (Bere and Westersjo, 2013; Stryamets et al., 2015).

Mycorrhizal fungi and saprotrophs were also mentioned as providers of cultural disservices predominantly related to "health and well-being". These reports concerned mainly poisonous species and trace elements accumulated in edible fungi as a hazard for human health. However, a few references indicated also a negative impact of fungi (or rather their picking) on social relations, i.e., clashes with environmental and property laws (Boa, 2004; de Román et al., 2006; Wright, 2010) or on spiritual religious values, as some religions demonstrate suspicious attitude toward fungi (Yamin-Pasternak, 2011). The impact of fungi on culture was much more variable geographically than any other biotic group, the variability stemming from the society's attitude toward fungi, first identified by Wasson and Wasson (1957) and later named by Hawksworth (1996) as "mycophobia" and "mycophilia." Depending on whether the country or region is "mycophobic" (fearing/indifferent to fungi) or "mycophilic" (fond of fungi), there would also be differences in biodiversity of fungal species that provide Cultural Services or disservices.
Different types of mycorrhizae show different nutrient fluxes, different fungal structures and consequently different carbon fluxes into the soil (Read, 1991; Read and Perez-Moreno, 2003; Churchland and Grayston, 2014). Diversity of AMF species was reported to promote soil carbon storage (Rillig, 2004) and fungal diversity increased $\mathrm{C}$ fluxes through an increased production of mycelial biomass and an increased decomposition of dead mycelial material (Wilkinson et al., 2011, 2012). This further suggests an effect of fungal diversity on climate regulation. The enzymatic activities were shown to vary across species and for increasing fungal diversity the total activity of nutrient mobilizing enzymes was increased (Courty et al., 2005) and more in general decomposition of organic matter was enhanced (Tiunov and Scheu, 2005; Courty et al., 2010; Rajala et al., 2012; Creamer et al., 2016). Positive effects on $\mathrm{N}, \mathrm{P}, \mathrm{Mg}$, or Fe cycles, their mobilization or their incorporation in plant tissues were reported for higher fungal diversity (Tremolières et al., 1998; Calvaruso et al., 2007; Leski et al., 2010; Velmala et al., 2014). However, such effects were shown to depend on the tree species (Lang and Polle, 2011), and in case of young trees a diversity of only one or two ECM species was better for the nutrition of the seedlings than a higher fungal diversity (Velmala et al., 2013). Although, the fungal efficiency for carbon cycling was higher for increasing diversity, this was mostly so at the species poor end of the diversity gradient (Setälä and McLean, 2004). In addition, within highly diverse fungal populations, distributed through different soil horizons, less abundant species make an important contribution to decomposition processes in soils (Baldrian et al., 2012). Bödeker et al. (2016) have shown that mycorrhizal and saprotrophic fungal guilds compete for the same organic substrates but still differently affect organic matter decomposition though differential enzyme production. Overall, a higher fungal diversity may result in the exploitation of different niches and soil layers, and through the combination of the contributions of species having all specialized enzymatic activities and through their different fungal structures and lifespan, they generate different carbon and nutrient storage processes, and the associated microorganisms depend on these fungi for their carbon, energy, and nutrients. A variety of uses has evolved from mushroom picking and this generates a myriad of services to humans.

\section{Prokaryota}

Microbial diversity is commonly explained by different tree species and associated litter and soil quality, including acidity. Soil $\mathrm{pH}$ is a major driver of soil bacteria, and when the chemical composition of evergreen litter leads to lower soil $\mathrm{pH}$ in coniferous forests, this can shape the microbial community composition (Lladó et al., 2018). According to Lauber et al. (2009), the overall phylogenetic diversity of bacteria in soils with a low $\mathrm{pH}$ is distinctly lower than in soils with a neutral $\mathrm{pH}$. At a low $\mathrm{pH}$, Actinobacteria and Bacteriodetes are less abundant, in contrast to Acidobacteria which occur at higher abundances (Lauber et al., 2009). Hence, species-rich broadleaved forests with a more neutral $\mathrm{pH}$ have a positive effect on the supply of "genetic resources". Studies of bacterial 
biodiversity enhanced knowledge of biological and biochemical functions of soil by taking into consideration the joined effects of biodiverse microbial communities (Frey-Klett et al., 2007; Burns et al., 2013). Several studies showed that belowground bacterial diversity related positively to nutrient cycling, carbon cycling or soil formation. Uroz et al. (2007) reported on the bacterial diversity in the ectomycorrhizosphere and the enhanced potential for mineral weathering in the forest soils they investigated. Calvaruso et al. (2010) further demonstrated that the oak and beech trees on this forest site have developed strategies in selecting the bacterial communities with the most efficient mineral weathering potentials, highlighting the role of bacterial diversity on soil formation through mineralization of primary, or secondary minerals. In another study, they demonstrated that a vertical diversity of bacterial communities permitted to weather minerals in the subsoil layers and to mobilize phosphorus and iron efficiently (Calvaruso et al., 2007).

Uroz et al. (2011) reviewed the characteristics of mineralweathering bacteria and showed that several genera have the ability to weather minerals and to improve tree nutrition. Salminen et al. (2010) indicated a variety of activities across the microbial community, but overall the relationship between diversity and enzymatic activity or $\mathrm{C}$ and $\mathrm{N}$ status was dominated by functional redundancy of the organisms within the community. Hättenschwiler et al. (2005) provided evidence that the diversity of decomposer organisms greatly influences litter decomposition and nutrient mineralization. In their study on the impact of birch added to a heather moorland, Mitchell et al. (2010) showed faster rates of nutrient cycling in presence of birch, where bacteria-dominated food webs are generally associated with faster rates of nutrient cycling. Bacteria immobilized $\mathrm{N}$ due to the relatively high $\mathrm{C}: \mathrm{N}$ ratios of their substrate, and microbial grazing stimulated bacterial turnover and thus stimulated $\mathrm{N}$ cycling (Schröter et al., 2003). Hättenschwiler et al. (2011), in their review, reported that despite functional redundancy, species richness facilitated species coexistence, increased the number of individuals, and increased cellulose decomposition in treatments with more than two species. However, for species diversity between two and ten species, redundancy could occur at any stage. Salminen et al. (2010) also reported that due to functional redundancy of soil organisms, the soil community composition of soil decomposers exerted no strong influence on $\mathrm{C}$ and $\mathrm{N}$ cycles in the soil.

Ammonia oxidizing archaea were evaluated for their effect on the regulation of water quality related to nitrification processes (Malchair and Carnol, 2013). Farrell et al. (2010) investigated hazard regulation in soil contaminated with $\mathrm{Cu}, \mathrm{Pb}$, and $\mathrm{Zn}$ and only a small effect of increased bacterial and fungal diversity on metal remediation could be observed. Ushio et al. (2013) investigated whether substrate quality could affect the relationship between microbial diversity and stability of soil decomposition activities. They demonstrated a positive diversitystability relationship for the soil microbial community. Changes in substrate quality, which could be induced by climate change, have impacts on decomposition processes and $\mathrm{CO}_{2}$ emissions from soils, but such impacts may be attenuated by the functional diversity of soil microbial communities (Ushio et al., 2013). The extracellular enzymes involved in carbon transformation largely determine the abundance of soil bacterial communities, while extracellular enzyme activities driving carbon oxidation were shown to regulate the abundance of saprophytic fungi (You et al., 2013). These findings demonstrate the complex interactions between plants, soil and microbial communities. Increased fungal:bacteria ratios were also associated with higher carbon sequestration (Bailey et al., 2002) and specific microorganisms have specific control on the production and consumption of many trace gasses relevant for climate and the chemical composition of the air (Conrad, 1996). In addition, abundant evidence was found for direct connections between shifts in the methane-cycling microbial community, due to climate and environmental changes, and observed methane flux levels (Aronson et al., 2013). Small organisms such as bacteria can thus be key drivers of energy and transformations of mineral and organic phases, resulting in often positive relationships between diversity and soil formation, nutrient and carbon cycling and presumably gas fluxes.

\section{Soil Fauna}

Soil fauna can be seen as ecosystem engineers who through their burrowing, degrading or feeding activities affect nutrient, carbon, and water cycles, can modify soil texture, supply supporting habitats for other faunal groups, and contribute to primary production (Lavelle et al., 1997). Several studies have addressed the abundance and diversity of soil fauna in relation to stand age, stand structure and tree stand diversity, but no general pattern emerged between aboveground diversity and genetic diversity of below ground communities, with both positive, neutral and negative relationships (Salamon et al., 2008; Salamon and Wolters, 2009; Chauvat et al., 2011; Cesarz et al., 2013; Korboulewsky et al., 2016; Mueller et al., 2016). Reversely, positive effects of diversity of soil fauna on nutrient cycling were reported for all the soil fauna groups considered and relate mostly to increased mineralization, litter degradation or trophic interactions between organisms, permitting the supply of nutrients for root uptake and subsequently to stimulate the delivery of fiber and fuel services. These positive to neutral relationships concern earthworms (e.g., Scheu, 2003; Jacob et al., 2009; Blouin et al., 2013; Rajapakshaa et al., 2014), enchytraeids (e.g., Swift et al., 1998; Schröter et al., 2003; Creamer et al., 2016), collembolans (e.g., Liiri et al., 2002; Lenoir et al., 2007; Jacob et al., 2009), mites (e.g. Heneghan and Bolger, 1996, 1998; Jacob et al., 2009), isopods (e.g., Coûteaux et al., 1991; Jacob et al., 2009), and nematodes (e.g., Laakso et al., 2000; Schröter et al., 2003).

As ecosystem engineers, earthworms contribute to multiple soil functions and associated services, however even for such a well-known group there is a notable absence of studies investigating earthworm diversity effects over those addressing presence of absence of individual species. The effect of earthworms on key soil functions such as soil structure and nutrient cycling and associated ecosystem services (e.g., water regulation, erosion control, primary production) are difficult to quantitatively assess, due to the complexity of soil systems (Kibblewhite et al., 2008; Blouin et al., 2013). In the individual case of earthworm effects on water regulation, for example; water 
infiltration and storage is influenced not only by the properties of the soil in question, but also by the wide variety of pore sizes and morphological characteristics produced by different ecological groups of earthworms (Peres et al., 1998; Shipitalo and Butt, 1999; Blouin et al., 2013). Earthworm diversity effects on primary production are equally complex, not least because earthworm-plant interactions are multidirectional and consist of both direct effects (e.g., root feeding) and indirect effects (e.g., through modifying soil structure), and these likewise differ between earthworm ecological groups (Brussaard, 1999; Scheu, 2003; Kukkonen et al., 2004). Primary production of birch and eucalyptus was stimulated by $25 \%$ by two interacting earthworm species in a field-based mesocosm experiment (Rajapakshaa et al., 2014). Positive effects of earthworms were reviewed by Blouin et al. (2013) who pointed amongst other benefits to the role of earthworms in pedogenesis, development of soil structure, nutrient cycling, and primary production. Similarly, Bullinger-Weber et al. (2007), investigating the soil structure under Salix spp. and Alnus incana in alluvial habitats, found out, that only when a silty texture was present, the presence of anecic earthworms was favored. Anecic earthworms increase the aggregate stabilization, with the iron forms in the coarse silt acting as cementing agents.

Phillips and FitzPatrick (1999), investigating several forest types in the USA and in Scotland, observed that broad-leaved trees such as Quercus spp. and Betula spp. produce a litter which encourages the presence of earthworms and enchytraeids, which then is responsible for the mixing of the topsoil. In contrast, pine and spruce needle litter are avoided by earthworms and partly by enchytraeids. Consequently, these forests have a thick organic horizon with no mixing of the topsoil. Thus, soil structure here is recognized as the Provisioning Service "platform". Earthworms and or enchytraeids were reported as biotic regulators of the communities of other soil fauna groups such as mites and centipedes (Coleman, 2008), protozoa (Bonkowski and Schaefer, 1997), and AMF families (Creamer et al., 2016). Their effect on air quality regulation through the effect on greenhouse gas emissions was not conclusive (Blouin et al., 2013; Lubbers et al., 2013). Earthworm activity is generally beneficial to water and erosion regulation, through the production of burrows and improvements in soil structure leading to increased water infiltration, soil porosity and water-holding capacity. Indeed, increased infiltration from earthworm burrows can decrease soil erosion by up to $50 \%$ and improve soil porosity and infiltration to $30 \mathrm{~cm}$ depth (Lavelle et al., 1997; Zeithaml et al., 2009; Blouin et al., 2013). These effects are increased by the diversity in size and arrangement of burrows and pores produced by different earthworm species and ecotypes (Blouin et al., 2013). Anecic earthworms in temperate climates may also increase surface roughness through the production of casts, which decrease surface run-off. Such species may also expose areas of bare soil to erosion through the removal of leaf litter during feeding, however this effect has not been demonstrated as significant (Hazelhoff et al., 1981; van Hooff, 1983).

Relationships between earthworm diversity and the impact on Cultural Services are generally difficult to assess because individual species are often not distinguished in folk taxonomy.
Indeed, in a lot of folklore and tradition earthworm species can be grouped together with other "worms" (Gamkrelidze and Ivanov, 1995; Sax, 2001). Nevertheless, Ulicsni et al. (2016) showed that a certain recognition of earthworm species exists even in folk understanding. Earthworm communities have a positive impact in burying and conserving heritage artifacts, as tools for environmental education, as fish bait for recreation, or in medical research (Decaëns et al., 2006; Cooper et al., 2012; Blouin et al., 2013). Earthworms were also depicted as symbols of Victorian aesthetics of death and decay (Sax, 2001) or objects of disgust (Cooper et al., 2012).

Effects of soil fauna on carbon cycling were described for their effect on litter decomposition, interaction with other trophic groups through grazing, respiration and mineralization of compounds rich in nutrients as $\mathrm{N}$ or $\mathrm{P}$. Such relationships were found for enchytraeids (Swift et al., 1998), collembolans (e.g., Liiri et al., 2002; Kanters et al., 2015), acari (Heneghan and Bolger, 1998; Laakso and Setälä, 1999; Liiri et al., 2002) and isopods (e.g., Vos et al., 2011; Collison et al., 2013). In their review, Nielsen et al. (2011) indicated a positive relationship between species richness and carbon cycling in almost all studies where the diversity gradient was low (manipulating only one group), while less frequently such relationships occurred in studies with greater richness. Laakso and Setälä (1999) manipulated soil animal communities in an experiment with birch seedlings and found that for reducing diversity of soil fauna, in particular of enchytraeids, plant $\mathrm{N}$ uptake and plant biomass development were reduced. In another experiment with birch, in the laboratory, the diversity of collembolans and acari positively affected primary production and nutrient uptake of the seedlings, but only at the species poor end of the diversity gradient (Liiri et al., 2002).

As described by Schröter et al. (2003), when C:N ratios of the substrate are relatively high, bacteria immobilize $\mathrm{N}$, while the fauna i.e., testate amoebae, nematodes, microarthropods, and enchytraeids, can counteract this $\mathrm{N}$ immobilization. Coûteaux et al. (1991) showed for later stages of decomposition of litter, that the rate of mineralization from high $\mathrm{C}: \mathrm{N}$ litter was related to the diversity of the food webs and became progressively higher with increasing complexity of the animal community up to a maximum of approximately $30 \%$ above controls. The review by Rusek (1998) recognized that Collembola play an important role in plant litter decomposition processes and in forming soil microstructure: they feed on many faunal groups and plant litter, are host to several parasites and are attacked by higher trophic level predators. The diversity of isopods positively affected, through interactions with other soil fauna and fungi, the formation of forest mull (David et al., 1993) and the early stages of litter decomposition (Harrop-Archibald et al., 2016). The greater decomposition rates in mull forest soil featuring a greater diversity in soil fauna, relative to species poorer moder forest soil, was also demonstrated by Schaefer and Schauermann (1990). For soil fauna and water cycling, only in the study by Laakso et al. (2000), for an increasing diversity of microbi-detritivores, more specifically nematodes, the water holding capacity was increased. Potapov et al. (2016) showed a positive effect of collembolan diversity 
on "supporting habitats" in a trophic niche approach. Diversity within communities of collembola (Ponge et al., 2003; Blasi et al., 2013; Urbanovičová et al., 2014; Reis et al., 2016), nematodes (George and Lindo, 2015), and algae (Temraleeva et al., 2011) are considered to be good tools for indication of various aspects of environmental quality.

Overall, soil fauna contributes in a complex manner to the provision of soil based ecosystem services, and in many studies the focus has not been on the diversity of a species group but rather on one key-species at a time. It is realistic to assume that the real influence of soil faunal diversity on ecosystem services is much larger than what could be found in the scientific literature so far. In particular, relative to Cultural Services, these are based on folk perception of nature and folk taxonomy, in which microscopic species are "invisible" and therefore non-existent (Hunn, 1999).

\section{Protists}

Studies of protozoan communities and their diversity help to understand the overall evolutionary history of life on earth and evolutionary patterns and processes (Mitchell et al., 2011; Heger et al., 2014). Several studies have investigated the ciliate protozoa throughout different contexts of soil $\mathrm{pH}$ (Foissner et al., 2005; Tikhonenkov et al., 2011; Domonell et al., 2013) and of forest species composition including Fagus, Fraxinus, Populus, Salix, Prunus, Betula, Populus, Tilia, Quercus, and Pinus. For the observed differences in ciliate diversity across forests, the number of cultivable protists did not increase so that the relationship between belowground diversity and genetic resources was termed neutral. Positive relationships between diversity of protozoa and primary production, and nutrient or carbon cycling occurred in several studies. Primary production of Norway spruce seedlings was increased in the presence of protozoa, and this was in particular so for the root system and in presence of mycorrhizae (Bonkowski et al., 2001). The protozoa increased the turnover and availability of nitrogen even though non-mycorrhizal spruce seedlings were apparently unable to use these additional nutrients (Bonkowski et al., 2001). Grazing by testate amoebae, amongst other faunal groups, counteracted $\mathrm{N}$ immobilization by bacteria feeding on high C:N substrates and thus affected nutrient cycling in a positive way (Schröter et al., 2003). Protozoans as compared to other faunal groups, made the largest contribution to $\mathrm{C}$ mineralisation (Schröter et al., 2003). Coleman (1994) argued that protozoan grazing stimulates mineralization and subsequent nutrient availability to plants and due to their high turnover rate could have a large impact on $\mathrm{C}$ and $\mathrm{N}$ cycles in the soil. So, protists can enhance overall nutrient turnover and growth rates of bacteria, as well as the decomposition of specific compounds (Adl and Gupta, 2006) and thus diversity of protozoans can have a positive effect on nutrient and carbon cycling or even primary production.

\section{The MEA Framework and Alternative Typologies}

The MEA (2005) has largely contributed in promoting the concept of ecosystem services, stressing the importance of the environment for actual and future human well-being.
Nevertheless, the MEA framework has been largely debated, with subsequent studies emphasizing on the need for a better definition of the concepts and terminology (Boyd and Banzhaf, 2007; Fisher et al., 2009; Haines-Young and Potschin, 2010; TEEB, 2010). With the objective of environmental accounting, Boyd and Banzhaf (2007) have insisted on the distinction of socalled intermediate and final goods, as intermediate goods could be double-counted if they also contribute to the provision of final goods. Brown et al. (2007), with the objective of valuating each service, also distinguished processes and functions from services, and services from benefits. They further introduced in their economic approach the willingness to pay, the willingness to accept compensation, the notions of rival or non-rival, respectively, exclusive and non-exclusive goods and services. From this perspective, functions or processes become services only if there are humans that benefit from them (Fisher et al., 2009). Assumingly, assigning a monetary value to ecosystem components that contribute to human well-being (services in the economic sense) would permit to protect the Earth's ecosystems and associated biodiversity better, and to maintain the capacity of ecosystems to fulfill services (Brown et al., 2007). Several concepts have been elaborated to improve the MEA framework, e.g., The Economics of Ecosystem and Biodiversity (TEEB, 2010), the Integrated Valuation of Ecosystem Services and Tradeoffs (Tallis and Polasky, 2009) or the Common International Classification for Ecosystem Services (Maes et al., 2016).

Haines-Young and Potschin (2010) have represented a cascade framework in which ecological structures, through functions and services are linked to human well-being. With the purposes of refining the definitions of the MEA framework and avoiding any double counting of services (in particular the supporting services), an organization in three ecosystem services categories has been proposed as an alternative: provisioning, cultural, and regulating combined with maintenance services (Maes et al., 2013, 2016). La Notte et al. (2017) reviewed the ES terminology and proposed to combine the cascade framework along with a system ecology approach, arguing that the distinction between intermediate and final services is overly reductionist. In their classification of the ecosystem services in the three categories provisioning, regulating and maintenance and cultural services (La Notte et al., 2017; Table 3), they developed a terminology chain from the cascade framework to the systems ecology category and how each service could be best assessed. The cascade framework depicted the services as "benefits", "functions", "services", "biophysical structures" or "values", while the systems ecology framework used the categories "(bio)mass", "interaction" or "information". This reorganization in three main categories (Maes et al., 2013, 2016) instead of four (MEA, 2005) may be clearer to economists, but has not reduced the variation in terminology, nor resolved how to assign a monetary value to each of these components of the ecosystem. The numbers of different ecosystem services distinguished in the different studies also vary greatly. There were $31 \mathrm{ES}$ in total for the MEA (2005), 22 for so-called soilbased ES in the European Atlas for Soil Biodiversity (Jeffery et al., 2010), 19 ES but few for cultural and supporting in the SEQ frame (Maynard et al., 2010), 17 ES but only one for 
cultural services in the study by Costanza et al. (1997), 48 in total in the comparison by La Notte et al. (2017; Table 3) and 37 in this study while focusing on belowground biodiversity. Differences in the appreciation exist between the studies and can also depend on the focus of the study; the decision context for the use of the ES concept is important here (Fisher et al., 2009). La Notte et al. (2017) highlighted that ecosystem assessments can be regrouped in those that are primarily bio-centered (i.e., biophysical structures, processes and functions related to the ecological sphere are considered as a whole in the accounting system) and those that have a human-centered approach (i.e., only those components which are relevant for the human end-use are included in the accounting system).

A criticism of the ES concept is that an anthropocentric focus excludes the idea of ecosystems and biodiversity as inherently valuable (Science for Environment Policy, 2015), and even natural capital is an anthropogenic term, while there is no evidence that monetization benefits biodiversity and ecosystem services (Silvertown, 2015). The latter defined ecosystem services as the goods and services of use to humans that are directly attributable to the ecological functioning of ecosystems, and distinguished non-use values, use values, and monetary values (Silvertown, 2015). Here, we targeted the inventory of ecosystem services associated to belowground biodiversity, in a broad way (from processes and functions to services/goods), without the objective of permitting to assign a monetary value to each service, or to evaluate the costs for substitution of lost services (sensu Brown et al., 2007; Table 2). We modified the scheme from Scholes et al. (2010) to illustrate how biodiversity conceptually relates to the different services and subsequently the human well-being (Figure 6). Following La Notte et al. (2017), it seems worthwhile, in the case of the contribution of belowground biodiversity to ecosystem services, to distinguish between the capacity of the ecosystem to supply services and its actual supply. Limiting the ecosystem services to only those depicted as "ecological insurance" or having "economic value" (Figure 6), would seem overly reductionist.

We agree with Silvertown (2015) that assigning a price to a service is a moral choice, not an economic imperative and share his fear that the use of market prices could transform a public good into a private source. Beyond this statement relative to the role of neoliberalism in ecology, we further agree with Silvertown (2015) that payment for ecosystem services is highly artificial, although we acknowledge that the use of monetary values can be an efficient eye-catcher to raise awareness (cf. Costanza et al., 1997). The issues with assigning prices to ecosystem services are related to the complexity of ecosystems, rendering it difficult to separate appropriately between intermediate and final services and benefits (Fisher et al., 2009), while the production of services could be spatially or temporally different from its consumption by mankind. Many services cannot be measured directly or manipulated experimentally (Cardinale et al., 2012); those associated to belowground biodiversity would in our opinion seem in majority non-rival, and non-exclusive. This makes them less prone to be incorporated in a monetary valuation system and results in a low likelihood for market exchange for the delivery of ecosystem services by belowground biodiversity. Furthermore, little is known on the marginal value of biodiversity in the provision of ecosystem services (Cardinale et al., 2012) and the fact that ecologists will in particular focus on intermediate ecosystem services (Birkhofer et al., 2015) will not make it easy to improve our understanding. Overall, from the bio-centered point of view, we think it would be impossible to cover all the intermediate and final services if a financial value has to be set. Therefore, assigning a monetary value to the services, in our opinion is morally and scientifically not appropriate, at least for our scope of evaluating ecosystem services associated with belowground biodiversity in forest soils.

\section{Overall Considerations}

Some services, like erosion regulation, can be categorized as both a Supporting and a Regulating Service depending on the time scale and immediacy of their impact on people (MEA, 2005), and this was described by de Bello et al. (2010) as clustering of ecosystem services. Therefore, some studies were valid for several combinations. Nonetheless, for the majority of ecosystem service-soil biota group combinations investigated, we found no study with exploitable results on the relationship between the group's belowground diversity and associated ecosystem services. Both the rationalized (standardized) key-word research and additional expert opinion assessments did not yield any study for these cases (374). In the other 144 cases, the relationships encountered were in the great majority of cases (71\%) based on only $1-3$ studies per combination, $14.5 \%$ on $4-7$ studies, and $14.5 \%$ on more 8 or more studies. This points to a predominance of lack of knowledge or limited evidence for many relationships. Whether this reflects the status of knowledge in this field, or whether our study missed relevant studies, could depend on the effectiveness of our key-word approach. Our sensitivity analysis (subset of four ecosystem services among the 37 of the list) using a broader set of key words gave only a few more studies and these did not change the pattern of the relationships. We checked for the potential bias of double-counting sources for more than one service and this showed a maximum of seven sources, irrespective of temporal or spatial scales. Hence, we are confident in the pertinence of our approach.

Specific difficulties arising in our investigations on ecosystem services and biodiversity relate to (i) the concepts of both ecosystem services and biodiversity, (ii) research focus of scientists and (iii) the valuation system. The common awareness of the ecosystem services concept (MEA framework, published in 2005) is rather recent and as such the key-words describing a given ecosystem service are continuously changing over time, meaning that these services were not always described in earlier works. In a similar manner, studies focussing on biodiversity loss were much rarer 10-15 years ago than they are now. In agreement with this, the large majority of the studies used in our work $(86 \%)$, was published since the year 2000. Scientists focus on particular aspects of biodiversity, or easily identifiable keystone species in their studies, manipulating the environment in some cases, but do not necessarily aim at linking the effect of an increasing (or decreasing) biodiversity gradient on ecosystem services. The valuation system of ecosystem services, 


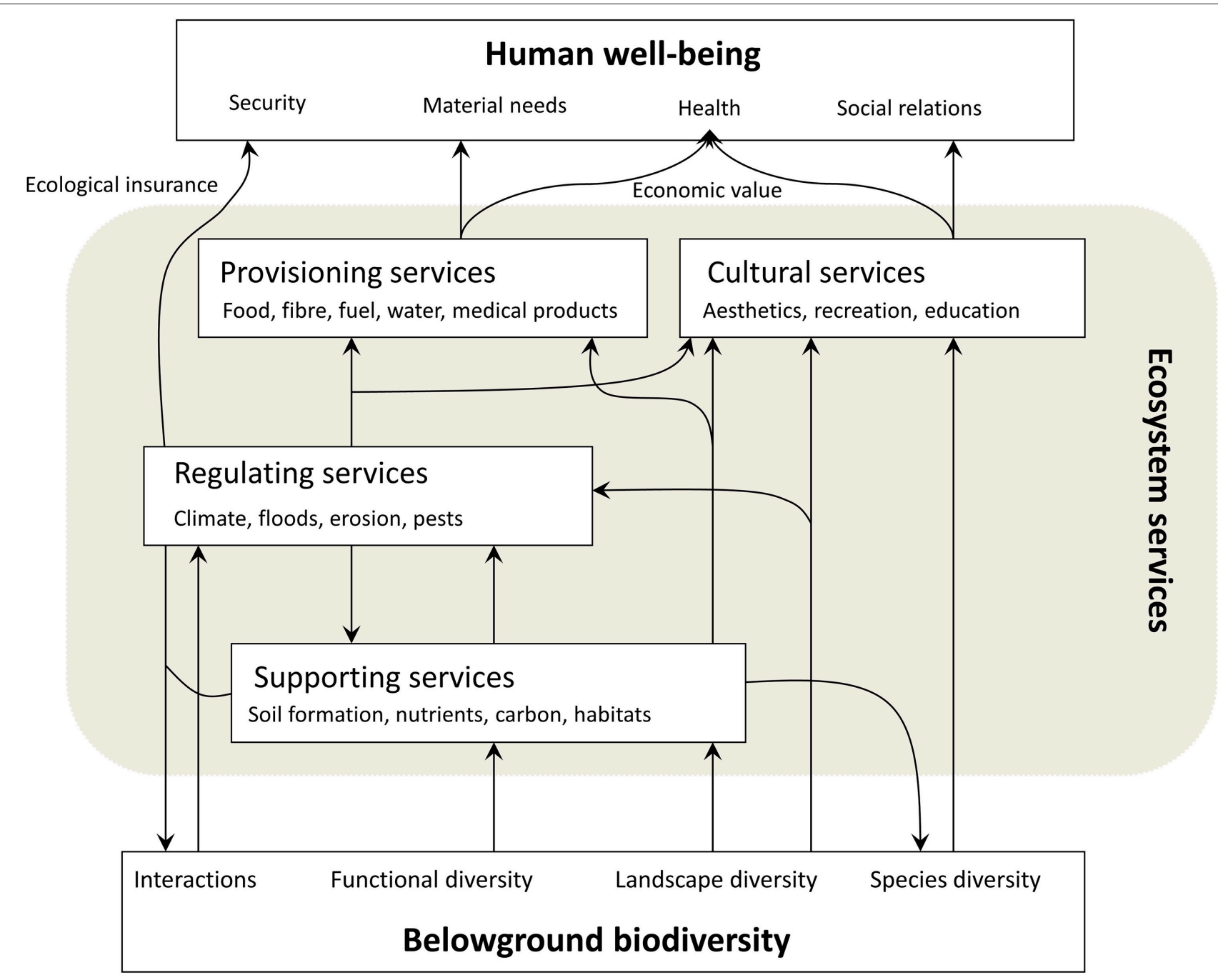

FIGURE 6 | A conceptual scheme of the relationships between belowground biodiversity, ecosystem services, and human well-being (modified from Scholes et al., 2010).

i.e., putting monetary values to the different services supplied, is not very well-developed across all services and this can bias the research directed to those services with established market values (e.g., those relevant to primary production). At the ecosystem service level, we expected a-priori larger numbers of studies for relationships between soil biota and Provisioning- and or Regulating Services. However, for both groups, quite often target species or species with a larger body size or with a specific chemical composition were the focus of the studies. Presence or absence of such species shows their particular role in supplying Provisioning Services or Regulating Services, but not the role of biodiversity within the relevant soil biota group. Cultural Services, on the other hand, are generally acknowledged as the most understudied, with the majority of these services dealing with landscapes or keystone species, underpinning individual Cultural Services, but rarely scale to biodiversity. This view is supported by our findings, suggesting well-studied contributions of individual soil biota groups but not the overall soil biodiversity. In addition, in the case of Cultural Services, there is a strong regional bias induced by the local culture. This is particularly clear for fungi, for which there were larger numbers of research papers examining cultural benefits (and dis-benefits) from fungi in those regions, which are termed as "mycophilous". Relative to Supporting Services, more relationships were documented than for Provisioning and Regulating Services, but it is not always easy to state whether a given process is purely a Supporting Service, or also can be considered a Provisioning or Regulating Service. For instance, soil formation can provide a platform for provisioning services, whereas nutrient-, carbon- and water cycling can affect the Regulating Services air quality, climate change, water cycling or erosion regulation.

Therefore, both the interest of scientist in these fields, as well as the terminology used to describe these fields, could affect the results and potentially lead to an underscoring of our results. 
However, within our group of experts, the proportion of studies that were not found directly (but added later), was rather small, and the use of a sensitivity analyses did not permit to find many more studies. Therefore, we believe, that our contribution reflects a genuine representation of published works for the European context. Being the European group of experts within the COST network, we focused on studies within Europe only, although some non-European studies were cited for comparison where this was relevant.

\section{CONCLUSIONS}

Our review of European literature showed that the majority of the studies reviewed found positive effects of belowground biodiversity and ecosystem services in forests (Figure 5), with the exception of fungi and Regulating Services (negative) and Regulating Services and protists (no data). However, less data were available for smaller taxa (prokaryota, protists) than for the other groupings and, in several biotic groupings, the use of key species was more common than the evaluation of biodiversity within those groupings. For a large proportion of all combinations of biotic groups and ecosystem services employing the MEA's ecosystem services descriptions, we did not find any manuscripts reporting on these specific relationships (72\%), or the detected relationships were based on only a few sources (20\%). Thus, for the large majority of biotic groups, our key word search approach shows, that we cannot conclude whether the diversity of such groups is associated with the delivery of ecosystem services. Well-designed experiments on belowground biodiversity are therefore needed to increase our understanding of the functions performed by the taxa, which occur in the soil and the roles that they play in the provision of ecosystem services.

\section{AUTHOR CONTRIBUTIONS}

All authors contributed to the design of our review process, with an organizing role of $\mathrm{MB}, \mathrm{IvB}$ and NS. Key-word searches were done by $\mathrm{MB}$ across all services groups with particular focus on soil fauna by $\mathrm{TB}, \mathrm{BB}, \mathrm{EO}, \mathrm{FA}, \mathrm{MC}, \mathrm{EV}$ and $\mathrm{HK}$, on

\section{REFERENCES}

Adl, M. S., and Gupta, V. V. S. R. (2006). Protists in soil ecology and forest nutrient cycling. Can. J. For. Res. 36, 1805-1817. doi: 10.1139/x06-056

Aponte, A., García, L. V., and Marañón, T. (2013). Tree species effects on nutrient cycling and soil biota: a feedback mechanism favouring species coexistence. For. Ecol. Manage. 309, 36-46. doi: 10.1016/j.foreco.2013.05.035

Aronson, E. L., Allison, S. D., and Helliker, B. R. (2013). Environmental impacts on the diversity of methane-cycling microbes and their resultant function. Front. Microbiol. 4:225. doi: 10.3389/fmicb.2013.00225

Bailey, V. L., Smith, J. L., and Bolton, H. (2002). Fungal-to-bacterial ratios in soils investigated for enhanced C sequestration. Soil Biol. Biochem. 34, 997-1007. doi: 10.1016/S0038-0717(02)00033-0

Baldrian, P., Kolarik, M., Stursova, M., Kopecky, J., Valaskova, V., Vetrovsky, T., et al. (2012). Active and total microbial communities in forest soil are fungi by NS, TP, LD, IsB, LS and on roots by TM, LM-M, and $\mathrm{AE}$. Assessments and analyses of searches were carried out for Provisioning services by $\mathrm{IvB}$, ÜP and $\mathrm{MB}$, for Regulating services by LD, LS, EV, FA, BB, IsB and EO, for Cultural Services by JM with help from TM, IO, IsB, IvB, EO and $\mathrm{BB}$, for Supporting services by LM-M, PC, DG, IM, IO, LV and MB. All authors contributed to the writing of the manuscript, with a leading role of MB. All authors have read and approved the submitted version.

\section{ACKNOWLEDGMENTS}

We are indebted to the COST Action FP1305 Biolink (Linking belowground diversity to ecosystem function), supported by COST (European Cooperation in Science and Technology, www.cost.eu), who gave financial support for our meetings and supplied the frame for our discussions and work sessions leading to this study. A further thank goes to the Research programme P4-0107 of the Slovenian Research Agency and EU FP7 Capacities project EUFORINNO (REGPOT No. 315982) for financial support (TM and $\mathrm{HK}$ ). AE received additional funding from the TAFER project, supported by Agropolis Fondation and SYSTRA under the reference ID 1200-014 and ID 1200013 through the Investissements d'avenir program (Labex Agro: ANR-10-LABX-001-01). IM acknowledges financial support by the DFG (grant no. ME 4156/2-1) and Volkswagen Foundation [grant no. 11-76251-99-34/13 (ZN 2928)]. IO was supported by the Center of Excellence: EcolChange (the European Regional Development Fund). JM acknowledges support from the Lithuanian Research Council (grant No MIP-17-5). LM-M acknowledges the FP7 European program as he was provided financial support with a Marie Curie IEF fellowship (ref. 626666/2013). PC acknowledges project support from the Czech Ministry of Education CR NPU LO1415.

\section{SUPPLEMENTARY MATERIAL}

The Supplementary Material for this article can be found online at: https://www.frontiersin.org/articles/10.3389/ffgc.2019. 00006/full\#supplementary-material largely different and highly stratified during decomposition. ISME J. 6, 248-258. doi: 10.1038/ismej.2011.95

Balvanera, P., Pfisterer, A. B., Buchmann, N., He, J.-S., Nakashizuka, T., Raffaelli, D., et al. (2006). Quantifying the evidence for biodiversity effects on ecosystem functioning and services. Ecol. Lett. 9, 1146-1156. doi: 10.1111/j.1461-0248.2006.00963.x

Balvanera, P., Siddique, I., Dee, L., Paquette, A., Isbell, F., Gonzalez, A., et al. (2014). Linking biodiversity and ecosystem services: current uncertainties and the necessary next steps. BioScience 64, 49-57. doi: 10.1093/bio sci/bit003

Barnosky, A. D., Matzke, N., Tomiya, S., Wogan, G. O. U., Swartz, B., Quental, T. B., et al. (2011). Has the Earth's sixth mass extinction already arrived? Nature 471, 51-57. doi: 10.1038/nature09678

Barrico, L., Azul, A. M., Morais, M. C., Coutinho, A. P., Freitas, H., and Castro, P. (2012). Biodiversity in urban ecosystems: plants and macromycetes 
as indicators for conservation planning in the city of Coimbra (Portugal). Landscape Urban Plan. 106, 88-102. doi: 10.1016/j.landurbplan.2012.02.011

Bastrup-Birk, A., Reker, J., and Zal, N. (2016). European Forest Ecosystems: State and Trends. Copenhagen, EEA Report No. 5/2016. Denmark: European Environment Agency.

Bauhus, J., Forrester, D. I., Gardiner, B., Jactel, H., Vallejo, R., and Pretzsch, H. (2017). "Ecological stability of mixed-species forests," in Mixed-Species Forests, eds. H. Pretzsch, D. I. Forrester, and J. Bauhus (Berlin: Springer), 337-382. doi: 10.1007/978-3-662-54553-9_7

Bere, E., and Westersjo, J. H. (2013). Nature trips and traditional methods for food procurement in relation to weight status. Scand. J. Public Health 41, 180-184. doi: $10.1177 / 1403494812471446$

Birkhofer, K., Diehl, E., Andersson, J., Ekroos, J., Früh-Müller, A., Machnikowski, F., et al. (2015). Ecosystem services - current challenges and opportunities for ecological research. Front. Ecol. Evol. 2:87. doi: 10.3389/fevo. 2014.00087

Blasi, S., Menta, C., Balducci, L., Conti, F. D., Petrini, E., and Piovesan, G. (2013). Soil microarthropod communities from Mediterranean forest ecosystems in Central Italy under different disturbances. Environ. Monit. Assess. 185, 1637-1655. doi: 10.1007/s10661-012-2657-2

Blouin, M., Hodson, M. E., Delgado, E. A., Baker, G., Brussaard, L., Butt, K. R., et al. (2013). A review of earthworm impact on soil function and ecosystem services. Eur. J. Soil Sci. 64, 161-182. doi: 10.1111/ejss. 12025

Boa, E. (2004). Wild Edible Fungi: a Global Overview of Their Use and Importance to People. Non-Wood Forest Products 17. Rome: FAO.

Bödeker, I. T. M., Lindahl, B. D., Olson, Å., and Clemmensen, K. E. (2016). Mycorrhizal and saprotrophic fungal guilds compete for the same organic substrates but affect decomposition differently. Funct. Ecol. 30, 1967-1978. doi: $10.1111 / 1365-2435.12677$

Bonet, J. A., Pukkala, T., Fischer, C. R., Palah, M., De, J. M., and Colinas, C. (2008). Empirical models for predicting the production of wild mushrooms in Scots pine (Pinus sylvestris L.) forests in the Central Pyrenees. Ann. For. Sci. 65:206. doi: 10.1051/forest:2007089

Bonkowski, M., Jentschke, G., and Scheu, S. (2001). Contrasting effects of microbial partners in the rhizosphere: interactions between Norway Spruce seedlings (Picea abies Karst.), mycorrhiza (Paxillus involutus (Batsch) Fr.) and naked amoebae (protozoa). Appl. Soil Ecol. 18, 193-204. doi: 10.1016/S0929-1393(01)00165-2

Bonkowski, M., and Schaefer, M. (1997). Interactions between earthworms and soil protozoa: a trophic component in the soil food web. Soil Biol. Biochem. 29, 499-502. doi: 10.1016/S0038-0717(96)00107-1

Boyd, J., and Banzhaf, S. (2007). What are ecosystem services? The need for standardized environmental accounting units. Ecol. Econ. 63, 616-626. doi: 10.1016/j.ecolecon.2007.01.002

Briones, M. J. I. (2014). Soil fauna and soil functions: a jigsaw puzzle. Front. Environ. Sci. 2:7. doi: 10.3389/fenvs.2014.00007

Brown, T. C., Bergstrom, J. C., and Loomis, J. B. (2007). Defining, valuing and providing ecosystem goods and services. Nat. Resources J. 47, 329-376. Available online at: http://www.jstor.org/stable/24889176

Brussaard, L. (1999). On the mechanisms of interactions between earthworms and plants. Pedobiologia 43, 880-885.

Bullinger-Weber, G., Le Bayon, R. C., Guenat, C., and Gobat, J. M. (2007). Influence of some physicochemical and biological parameters on soil structure formation in alluvial soils. Eur. J. Soil Biol. 43, 57-70. doi: 10.1016/j.ejsobi.2006.05.003

Burns, R. G., DeForest, J. L., Marxsen, J., Sinsabaugh, R. L., Stromberger, M. E., Wallenstein, M. D., et al. (2013). Soil enzymes in a changing environment: current knowledge and future directions. Soil Biol. Biochem. 58, 216-234. doi: 10.1016/j.soilbio.2012.11.009

Calvaruso, C., Turpault, M. P., Leclerc, E., and Frey-Klett, P. (2007). Impact of ectomycorrhizosphere on the functional diversity of soil bacterial and fungal communities from a forest stand in relation to nutrient mobilization processes. Microb. Ecol. 54, 567-577. doi: 10.1007/s00248-007-9260-z

Calvaruso, C., Turpault, M. P., Leclerc, E., Ranger, J., Garbaye, J., Uroz, S., et al. (2010). Influence of forest trees on the distribution of mineral weathering-associated bacterial communities of the Scleroderma citrinum mycorrhizosphere. Appl. Environ. Microbiol. 76, 4780-4787. doi: 10.1128/AEM.03040-09
Cardinale, B. J., Duffy, J. E., Gonzalez, A., Hooper, D. U., Perrings, C., Venail, P., et al. (2012). Biodiversity loss and its impact on humanity. Nature 486, 59-67. doi: $10.1038 /$ nature 11148

Carter, A. J. (2003). Myths and mandrakes. J. R. Soc. Med. 96, 144-147. doi: $10.1177 / 014107680309600312$

Cesarz, S., Ruess, L., Jacob, M., Jacob, A., Schaefer, M., and Scheu, S. (2013). Tree species diversity versus tree species identity: driving forces in structuring forest food webs as indicated by soil nematodes. Soil Biol. Biochem. 62, 36-45. doi: 10.1016/j.soilbio.2013.02.020

Chauvat, M., Titsch, D., Zaytsev, A. S., and Wolters, V. (2011). Changes in soil faunal assemblages during conversion from pure to mixed forest stands. For. Ecol. Manage. 262, 317-324. doi: 10.1016/j.foreco.2011.03.037

Christen, B., and Dalgaard, T. (2013). Buffers for biomass production in temperate European agriculture: a review and synthesis on function, ecosystem services and implementation. Biomass Bioenerg. 55, 53-67. doi: 10.1016/j.biombioe.2012.09.053

Churchland, C., and Grayston, S. J. (2014). Specificity of plant-microbe interactions in the tree mycorrhizosphere biome and consequences for soil C cycling. Front. Microbiol. 5:261. doi: 10.3389/fmicb.2014.00261

Coûteaux, M. M., Mousseau, M., Celerier, M. L., and Bottner, P. (1991). Increased atmospheric $\mathrm{CO}_{2}$ and litter quality - Decomposition of sweet chestnut leaf litter with animal food webs of different complexities. Oikos 61, 54-64. doi: $10.2307 / 3545406$

Coleman, D. C. (1994). "Compositional analysis of microbial communities," in Beyond the Biomass, eds. K. Ritz, J. Dighton, and K. E. Giller (Chichester: Wiley-Sayce), 201-220.

Coleman, D. C. (2008). From peds to paradoxes: linkages between soil biota and their influences on ecological processes. Soil Biol. Biochem. 40, 271-289. doi: 10.1016/j.soilbio.2007.08.005

Collison, E. J., Riutta, T., and Slade, E. M. (2013). Macrofauna assemblage composition and soil moisture interact to affect soil ecosystem functions. Acta Oecol. 47, 30-36. doi: 10.1016/j.actao.2012.12.002

Conrad, R. (1996). Soil microorganisms as controllers of atmospheric trace gases ( $\mathrm{H}-2, \mathrm{CO}, \mathrm{CH}_{4}, \mathrm{OCS}, \mathrm{N}_{2} \mathrm{O}$, and NO). Microbiol. Rev. 60, 609-640.

Cooper, E. L., Balamurugan, M., Huang, C.-Y., Tsao, C. R., Heredia, J., TommaseoPonzetta, M., et al. (2012). Earthworms dilong: ancient, inexpensive, noncontroversial models may help clarify approaches to integrated medicine emphasizing neuroimmune systems. Evidence-Based Complement Alternat. Med. 2012:164152. doi: 10.1155/2012/164152

Costanza, R., d'Arge, R., de Groot, R., Farber, S., Grasso, M., Hannon, B., et al. (1997). The value of the world's ecosystem services and natural capital. Nature 387, 253-260.

Courty, P. E., Franc, A., and Garbaye, J. (2010). Temporal and functional pattern of secreted enzyme activities in an ectomycorrhizal community. Soil Biol. Biochem. 42, 2022-2025. doi: 10.1016/j.soilbio.2010.07.014

Courty, P. E., Pritsch, K., Schloter, M., Hartmann, A., and Garbaye, J. (2005). Activity profiling of ectomycorrhizal communities in two forest soils using multiple enzymatic tests. New Phytol. 167, 309-319. doi: 10.1111/j.1469-8137.2005.01401.x

Creamer, R. E., Hannula, S. E., Leeuwen, J. P. V., Stone, D., Rutgers, M., Schmelz, R. M., et al. (2016). Ecological network analysis reveals the inter-connection between soil biodiversity and ecosystem function as affected by land use across Europe. Appl. Soil Ecol. 97, 112-124. doi: 10.1016/j.apsoil.2015.08.006

Danielsen, L., Thurmer, A., Meinicke, P., Buee, M., Morin, E., Martin, F., et al. (2012). Fungal soil communities in a young transgenic poplar plantation form a rich reservoir for fungal root communities. Ecol. Evol. 2, 1935-1948. doi: $10.1002 /$ ece3.305

David, J. F., Ponge, J. F., and Delecour, F. (1993). The saprophagous macrofauna of different types of humus in beech forests of the Ardenne (Belgium). Pedobiologia 37, 49-56.

Dawud, S. M., Raulund-Rasmussen, K., Domisch, T., Finér, L., Jaroszewicz, B., and Vesterdal, L. (2016). Is tree species diversity or species identity the more important driver of soil carbon stocks, $\mathrm{C} / \mathrm{N}$ ratio, and $\mathrm{pH}$ ? Ecosystems 19, 645-660. doi: 10.1007/s10021-016-9958-1

de Bello, F., Lavorel, S., Díaz, S., Harrington, R., Cornelissen, J. H. C., Bardgett, R. D., et al. (2010). Towards an assessment of multiple ecosystem processes and services via functional traits. Biodivers. Conserv. 19, 2873-2893. doi: $10.1007 /$ s10531-010-9850-9 
de Groot, R. S., Alkemade, R., Braat, L., Hein, L., and Willemen, L. (2010). Challenges in integrating the concept of ecosystem services and values in landscape planning, management and decision making. Ecol. Complex. 7, 260-272. doi: 10.1016/j.ecocom.2009.10.006

de Román, M., Boa, E., and Woodward, S. (2006). Wild-gathered fungi for health and rural livelihoods. Proc. Nutr. Soc. 65, 190-197. doi: 10.1079/ PNS2006491

Decaëns, T., Jiménez, J. J., Gioia, C., Measey, G. J., and Lavelle, P. (2006). The values of soil animals for conservation biology. Eur. J. Soil Biol. 42 (Suppl. 1), S23-S38. doi: 10.1016/j.ejsobi.2006.07.001

Díaz, S., Fargione, J., Chapin, F. S., and Tilman, D. (2006). Biodiversity loss threatens human well-being. PLoS Biol. 4:e277. doi: 10.1371/journal.pbio.0040277

Díaz, S., Pascual, U., Stenseke, M., Martin-Lopez, B., Watson, R., Molnar, Z., et al. (2018). Assessing nature's contributions to people. Science 359, 270-272. doi: $10.1126 /$ science.aap8826

Domisch, T., Finer, L., Dawud, S. M., Vesterdal, L., and Raulund-Rasmussen, K. (2015). Does species richness affect fine root biomass and production in young forest plantations? Oecologia 177, 581-594. doi: 10.1007/s00442-014-3 107-3

Domonell, A., Brabender, M., Nitsche, F., Bonkowski, M., and Arndt, H. (2013). Community structure of cultivable protists in different grassland and forest soils of Thuringia. Pedobiologia 56, 1-7. doi: 10.1016/j.pedobi.2012.07.001

Ducic, T., Berthold, D., Langenfeld-Heyser, R., Beese, F., and Polle, A. (2009). Mycorrhizal communities in relation to biomass production and nutrient use efficiency in two varieties of Douglas fir (Pseudotsuga menziesii var. menziesii and var. glauca) in different forest soils. Soil Biol. Biochem. 41, 742-753. doi: 10.1016/j.soilbio.2009.01.013

Dugan, F. M. (2008a). Fungi, folkways and fairy tales: mushrooms \& mildews in stories, remedies \& rituals, from Oberon to the Internet. North Am. Fungi 3, 23-72. doi: 10.2509/naf2008.003.0074

Dugan, F. M. (2008b). Fungi in the Ancient World: How Mushrooms, Mildews, Molds and Yeast Shaped the Early Civilizations of Europe, the Mediterranean and the Near East. St. Paul, MN: APS Press. 140.

Egli, S. (2011). Mycorrhizal mushroom diversity and productivity-an indicator of forest health? Ann. For. Sci. 68, 81-88. doi: 10.1007/s13595-010-0009-3

Ellis, E. C., Klein Goldewijk, K. K., Siebert, S., Lightman, D., and Ramankutty, N. (2010). Anthropogenic transformation of the biomes, 1700 to 2000. Global Ecol. Biogeogr. 19, 589-606. doi: 10.1111/j.1466-8238.2010.00540.x

FAO (2016). State of the World's Forests 2016. Forests and Agriculture: Land-use Challenges and Opportunities. Rome:FAO.

Farrell, M., Griffith, G. W., Hobbs, P. J., Perkins, W. T., and Jones, D. L. (2010). Microbial diversity and activity are increased by compost amendment of metal-contaminated soil. FEMS Microbiol. Ecol. 71, 94-105. doi: 10.1111/j.1574-6941.2009.00793.x

Fisher, B., Turner, R. K., and Morling, P. (2009). Defining and classifying ecosystem services for 1175 decision making. Ecol. Econ. 68, 643-653. doi: 10.1016/j.ecolecon.2008.09.014

Foissner, W., Berger, H., Xu, K., and Zechmeister-Boltenstern, S. (2005). A huge, undescribed soil ciliate (Protozoa: Ciliophora) diversity in natural forest stands of Central Europe. Biodivers. Conserv. 14, 617-701. doi: 10.1007/s10531-004-3923-6

Frey-Klett, P., Garbaye, J., and Tarkka, M. (2007). The mycorrhiza helper bacteria revisited. New Phytol. 176, 22-36. doi: 10.1111/j.1469-8137.2007.02191.x

Gamfeldt, L., Snall, T., Bagchi, R., Jonsson, M., Gustafsson, L., Kjellander, P., et al. (2013). Higher levels of multiple ecosystem services are found in forests with more tree species. Nat. Commun. 4:1340. doi: 10.1038/ncomms2328

Gamkrelidze, T.V., and Ivanov, V.V. (1995). Indo-European and the IndoEuropeans: a Reconstruction and Historical Analysis of ProtoLanguage and Protoculture. Berlin; New York, NY: Mouton de Gruyter. doi: $10.1515 / 9783110815030$

Garibay-Orijel, R., Ramírez-Terrazo, A., and Ordaz-Velázqez, M. (2012). Women care about local knowledge, experiences from ethnomycology. J. Ethnobiol. Ethnomed. 8, 1-12. doi: 10.1186/1746-4269-8-25

Gaston, K.J. (2010). "Biodiversity," in Conservation Biology for All, eds. N. S. Sodhi and P. R. Ehrlich (New York, NY: Oxford University Press Inc), 27-44. doi: 10.1093/acprof:oso/9780199554232.00 3.0003
George, P. B. L., and Lindo, Z. (2015). Application of body size spectra to nematode trait-index analyses. Soil Biol. Biochem. 84, 15-20. doi: 10.1016/j.soilbio.2015.02.007

Gómez-Aparicio, L., Ibáñez, B., Serrano, M. S., De Vita, P., Ávila, J. M., PérezRamos, I.M., et al. (2012). Spatial patterns of soil pathogens in declining Mediterranean forests: implications for tree species regeneration. New Phytol. 194, 1014-1024. doi: 10.1111/j.1469-8137.2012.04108.x

Grossiord, C.; Gessler, A., Granier, A., Berger, S., Brechet, C., Hentschel, R., et al. (2014). Impact of interspecific interactions on the soil water uptake depth in a young temperate mixed species plantation. J. Hydrol. 519, 3511-3519. doi: 10.1016/j.jhydrol.2014.11.011

Guckland, A., Jacob, M., Flessa, H., Thomas, F. M., and Leuschner, C. (2009). Acidity, nutrient stocks, and organic-matter content in soils of a temperate deciduous forest with different abundance of European beech (Fagus sylvatica L.). J. Plant Nutr. Soil Sci. 172, 500-511. doi: 10.1002/jpln.200800072

Gundale, M. J., Wardle, D. A., and Nilsson, M.-C. (2010). Vascular plant removal effects on biological $\mathrm{N}$ fixation vary across a boreal forest island gradient. Ecology 91, 1704-1714. doi: 10.1890/09-0709.1

Gyozo, Z. (2010). The meanings and functions of mushrooms as food in Hungarian folk tradition. Acta Ethnogr. Hung. 55, 115-138. doi: 10.1556/AEthn.55.2010.1.8

Haines-Young, R., and Potschin, M. (2010). "The links between biodiversity, ecosystem services and human well-being. Chapter 6.", in Ecosystem Ecology: A New Synthesis, eds. D. G. Raffaelli and C. L. J. Frid. BES Ecological Reviews Series (Cambridge: CUP), 110-139. doi: 10.1017/CBO9780511750458.007

Halme, P., Holec, J., and Heilman-Clausen, J. (2017). The history and future of fungi as biodiversity surrogates in forests. Fungal Ecol. 27, 193-201. doi: 10.1016/j.funeco.2016.10.005

Hanski, I., von Hertzen, L., Fyhrquist, N., Koskinen, K., Torppa, K., Laatikainen, T., et al. (2012). Environmental biodiversity, human microbiota, and allergy are interrelated. PNAS 109, 8334-8339. doi: 10.1073/pnas.1205624109

Härkönen, M. (1998). Uses of mushrooms by Finns and Karelians. Int. J. Circumpolar Health 57, 40-55.

Harrop-Archibald, H., Didham, R. K., Standish, R. J., Tibbett, M., and Hobbs, R. J. (2016). Mechanisms linking fungal conditioning of leaf litter to detritivore feeding activity. Soil Biol. Biochem. 93, 119-130. doi: 10.1016/j.soilbio.2015.10.021

Hättenschwiler, S., Fromin, N., and Barantal, S. (2011). Functional diversity of terrestrial microbial decomposers and their substrates. C.R. Biol. 334, 393-402. doi: 10.1016/j.crvi.2011.03.001

Hättenschwiler, S., Tiunov, A. V., and Scheu, S. (2005). Biodiversity and litter decomposition in terrestrial ecosystems. Annu. Rev. Ecol. Evol. S. 36, 191-218. doi: 10.1146/annurev.ecolsys.36.112904.151932

Hawksworth, D. L. (1996). Mycophobia and mycophilia. Nature 379, 503-504. doi: $10.1038 / 379503 \mathrm{a} 0$

Hazelhoff, L., van Hoof, P., Imeson, A. C., and Kwaad, F. J. P. M. (1981). The exposure of forest soil to erosion by earthworms. Earth Surf. Proc. Land. 6, 235-250. doi: 10.1002/esp.3290060305

Heger, T. J., Edgcomb, V. P., Kim, E., Lukeš, J., Leander, B. S., and Yubuki, N. (2014). A resurgence in field research is essential to better understand the diversity, ecology, and evolution of microbial Eukaryotes. J. Eukaryot. Microbiol. 61, 214-223. doi: 10.1111/jeu.12095

Heilmann-Clausen, J., Barron, E. S., Boddy, L., Dahlberg, A., Griffith, G. W., Nordén, J., et al. (2015). A fungal perspective on conservation biology. Conserv. Biol. 29, 61-68. doi: 10.1111/cobi.12388

Heleno, S. A., Barros, L., Sousa, M. J., Martins, A., and Ferreira, I. C. F. R. (2010). Tocopherols composition of Portuguese wild mushrooms with antioxidant capacity. Food Chem. 119, 1443-1450. doi: 10.1016/j.foodchem.2009.09.025

Heneghan, L., and Bolger, T. (1996). Effect of components of 'acid rain' on the contribution of soil microarthropods to ecosystem function. J. Appl. Ecol. 33, 1329-1344. doi: 10.2307/2404774

Heneghan, L., and Bolger, T. (1998). Soil microarthropod contribution to forest ecosystem processes: the importance of observational scale. Plant Soil 205, 113-124. doi: 10.1023/A:1004374912571

Hernández-Rodríguez, M., de-Miguel, S., Pukkala, T., Oria-de-Rueda, J. A., and Martín-Pinto, P. (2015). Climate-sensitive models for mushroom yields and diversity in Cistus ladanifer scrublands. Agr. For. Meteorol. 213, 173-182. doi: 10.1016/j.agrformet.2015.07.001 
Hinsinger, P., Bengough, A. G., Vetterlein, D., and Young, I. M. (2009). Rhizosphere: biophysics, biogeochemistry and ecological relevance. Plant Soil 321, 117-152. doi: 10.1007/s11104-008-9885-9

Hoeksema, J. D., Chaudhary, V. B., Gehring, C. A., Johnson, N. C., Karst, J., Koide, R. T., et al. (2010). A meta-analysis of context-dependency in plant response to inoculation with mycorrhizal fungi. Ecol. Lett. 13, 394-407. doi: 10.1111/j.1461-0248.2009.01430.x

Hooper, D. U., Adair, E. C., Cardinale, B. J., Byrnes, J. E. K., Hungate, B. A., Matulich, K. L., et al. (2012). A global synthesis reveals biodiversity loss as a major driver of ecosystem change. Nature 486, 105-108. doi: $10.1038 /$ nature11118

Hunn, E. S. (1999). "Size as limiting the recognition of biodiversity in folkbiological classifications: One of four factors governing the cultural recognition of biological taxa," in Folkbiology, eds. D. L. Medin and S. Atran (Cambridge: MIT Press), 47-69.

Ivancheva, S., and Stantcheva, B. (2000). Ethnobotanical inventory of medicinal plants in Bulgaria. J. Ethnopharmacol. 69, 165-172. doi: 10.1016/S0378-8741(99)00129-4

Jacob, A., Hertel, D., and Leuschner, C. (2014). Diversity and species identity effects on fine root productivity and turnover in a species-rich temperate broad-leaved forest. Funct. Plant Biol. 41, 678-689. doi: 10.1071/FP13195

Jacob, M., Weland, N., Platner, C., Schaefer, M., Leuschner, C., and Thomas, F. M. (2009). Nutrient release from decomposing leaf litter of temperate deciduous forest trees along a gradient of increasing tree species diversity. Soil Biol. Biochem. 41, 2122-2130. doi: 10.1016/j.soilbio.2009.07.024

Jeffery, S., Gardi, C., Jones, A., Montanarella, L., Marmo, L., Miko, L., et al., (eds). (2010). European Atlas of Soil Biodiversity. Luxemburg: European Commission, Publications Office of the European Union. 128.

Johann, E., Agnoletti, M., Axelsson, A.-L., Bürgi, M., and Östlund, L., Rochel, X., et al. (2004). "History of secondary spruce forests in Europe," in Norway Spruce Conversion - Options and Consequences, eds. H. Spiecker, J. Hansen, E. Klimo, J. P. Skovsgaard, H. Sterba, K. von Teuffel. EFI Research Report 18. (Brill: Leiden), 25-62.

Jonsson, L., Nilsson, M.-C., Wardle, D. A., and Zackrisson, O. (2001). Context dependent effects of ectomycorrhizal species richness on tree seedling productivity. Oikos 93, 353-364. doi: 10.1034/j.1600-0706.2001.930301.x

Jucker, T., Bouriaud, O., Avacaritei, D., and Coomes, D. A. (2014). Stabilizing effects of diversity on aboveground wood production in forest ecosystems: linking patterns and processes. Ecol. Lett. 17, 1560-1569. doi: 10.1111/ele.12382

Kanters, C., Anderson, I. C., and Johnson, D. (2015). Chewing up the woodwide web: selective grazing on ectomycorrhizal fungi by Collembola. Forests 6, 2560-2570. doi: 10.3390/f6082560

Kibblewhite, M. G., Ritz, K., and Swift, M. J. (2008). Soil health in agricultural systems. Philos Trans R. Soc. Lond. Ser. B. Biol. Sci. 363, 685-701. doi: 10.1098/rstb.2007.2178

Kiernan, G. (2010). "Fungal monsters in Science fiction," in From Another Kingdom. The Amazing World of Fungi, eds. L. Boddy and M. Coleman (Edinburgh: RBG), 105-120.

Kolström, M., and Lumatjarvi, J. (1999). Decision support system for studying effect of forest management on species richness in boreal forests. Ecol. Model. 119, 43-55. doi: 10.1016/S0304-3800(99)00060-5

Korboulewsky, N., Perez, G., and Chauvat, M. (2016). How tree diversity affects soil fauna diversity: a review. Soil Biol. Biochem. 94, 94-106. doi: 10.1016/j.soilbio.2015.11.024

Kukkonen, S., Palojarvi, A., Rakkolainen, M., and Vestberg, M. (2004). Peat amendment and production of different crop plants affect earthworm populations in field soil. Soil Biol. Biochem. 36, 415-423. doi: 10.1016/j.soilbio.2003.10.017

La Notte, A., D’Amato, D., Mäkinen, H., Paracchini, M. L., Liquete, C., Enoh, B., et al. (2017). Ecosystem services classification: a systems ecology perspective of the cascade framework. Ecol. Indic. 74, 392-402. doi: 10.1016/j.ecolind.2016.11.030

Laakso, J., and Setälä, H. (1999). Sensitivity of primary production to changes in the architecture of belowground food webs. Oikos 87, 57-64. doi: 10.2307/ 3546996

Laakso, J., Setälä, H., and Palojärvi, A. (2000). Influence of decomposer food web structure and nitrogen availability on plant growth. Plant Soil 225, 153-165. doi: 10.1023/A:1026534812422
Lang, C., and Polle, A. (2011). Ectomycorrhizal fungal diversity, tree diversity and root nutrient relations in a mixed Central European forest. Tree Physiol. 31, 531-538. doi: 10.1093/treephys/tpr042

Lauber, C. L., Hamady, M., Knight, R., and Fierer, N. (2009). Pyrosequencingbased assessment of soil $\mathrm{pH}$ as a predictor of soil bacterial community composition at the continental scale. Appl. Environ. Microbiol. 75, 5111-5120. doi: 10.1128/AEM.00335-09

Lavelle, P., Bignell, D., Lepage, M., Wolters, V., Roger, P., Ineson, P., et al. (1997). Soil function in a changing world: the role of invertebrate ecosystem engineers. Eur. J. Soil Biol. 33, 159-193.

Lei, P., Scherer-Lorenzen, M., and Bauhus, J. (2012). The effect of tree species diversity on fine-root production in a young temperate forest. Oecologia 169, 1105-1115. doi: 10.1007/s00442-012-2259-2

Lenoir, L., Persson, T., Bengtsson, J., Wallander, H., and Wirén, A. (2007). Bottomup or top-down control in forest soil microcosms? Effects of soil fauna on fungal biomass and C/N mineralisation. Biol. Fertil. Soils 43, 281-294. doi: 10.1007/s00374-006-0103-8

Leporatti, M. L., and Ivancheva, S. (2003). Preliminary comparative analysis of medicinal plants used in the traditional medicine of Bulgaria and Italy. $J$. Ethnopharmacol. 87, 123-142. doi: 10.1016/S0378-8741(03)00047-3

Leski, T., Aučina, A., Skridaila, A., Pietras, M., Piepšas, E., and Rudawska, M. (2010). Ectomycorrhizal community structure of different genotypes of Scots pine under forest nursery conditions. Mycorrhiza 20, 473-481. doi: 10.1007/s00572-010-0298-2

Liiri, M., Setälä, H., Haimi, J., Pennanen, T., and Fritze, H. (2002). Relationship between soil microarthropod species diversity and plant growth does not change when the system is disturbed. Oikos 96, 137-149. doi: 10.1034/j.1600-0706.2002.960115.x

Liu, J., Gao, G., Wang, S., Jiao, L., Wu, X., and Fu, B. (2018). The effects of vegetation on runoff and soil loss: Multidimensional structure analysis and scale characteristics. J. Geograph. Sci. 28, 59-78. doi: $10.1007 / \mathrm{s} 11442-018-1459-\mathrm{z}$

Lladó, S., López-Mondéjar, R., and Baldrian, P. (2018). Drivers of microbial community structure in forest soils. Appl. Microbiol. Biot. 102, 4331-4338. doi: 10.1007/s00253-018-8950-4

Lubbers, I. M., van Groenigen, K. J., Fonte, S. J., Six, J., Brussaard, L., and van Groenigen, J. W. (2013). Greenhouse-gas emissions from soils increased by earthworms. Nat. Clim. Change 3, 187-194. doi: 10.1038/nclimate1692

Luczaj, L., and Nieroda, Z. (2011). Collecting and learning to identify edible fungi in Southeastern Poland: age and gender differences. Ecol. Food Nutr. 50, 319-336. doi: 10.1080/03670244.2011.586314

Luyssaert, S., Marie, G., Valade, A., Chen, Y. Y., Djomo, S. N., and Ryder, J. (2018). Trade-offs in using European forests to meet climate objectives. Nature 562, 259-262. doi: 10.1038/s41586-018-0577-1

Mace, G. M., Norris, K., and Fitter, A. H. (2012). Biodiversity and ecosystem services: a multilayered relationship. Trends Ecol. Evol. 27, 19-25. doi: $10.1016 / j$. tree.2011.08.006

Maes, J., Liquete, C., Teller, A., Erhard, M., Paracchini, M. L., Barredo, J. I., et al. (2016). An indicator framework for assessing ecosystem services in support of the EU Biodiversity Strategy to 2020. Ecosyst. Serv. 17, 14-23. doi: 10.1016/j.ecoser.2015.10.023

Maes, J., Teller, A., Erhard, M., Liquete, C., Braat, L., Berry, P., et al. (2013). Mapping and Assessment of Ecosystems and Their Services. An Analytical Framework for Ecosystem Assessments Under Action 5 of the EU Biodiversity Strategy to 2020. Luxemburg: Publications of the European Union.

Malchair, S., and Carnol, M. (2013). AOB community structure and richness under European beech, sessile oak, Norway spruce and Douglas-fir at three temperate forest sites. Plant Soil 366, 521-535. doi: 10.1007/s11104-012-1450-x

Maynard, S., James, D., and Davidson, A. (2010). The development of an ecosystem services framework for South East Queensland. Environ. Manage. 45, 881-895. doi: $10.1007 / \mathrm{s} 00267-010-9428-\mathrm{z}$

MEA (2005). Millennium Ecosystem Assessment. Ecosystems and Human Wellbeing: Synthesis. Washington, DC: Island Press 155.

Meinen, C., Hertel, D., and Leuschner, C. (2009a). Root growth and recovery in temperate broad-leaved forest stands differing in tree species diversity. Ecosystems 12, 1103-1116. doi: 10.1007/s10021-009-9271-3

Meinen, C., Hertel, D., and Leuschner, C. (2009c). Biomass and morphology of fine roots in temperate broad-leaved forests differing in tree species diversity: 
is there evidence of below-ground overyielding? Oecologia 161, 99-111. doi: 10.1007/s00442-009-1352-7

Meinen, C., Leuschner, C., Ryan, N. T., and Hertel, D. (2009b). No evidence of spatial root system segregation and elevated fine root biomass in multispecies temperate broad-leaved forests. Trees-Struct. Funct. 23, 941-950. doi: 10.1007/s00468-009-0336-x

Metcalfe, D. B., Fisher, R. A., and Wardle, D. A. (2011). Plant communities as drivers of soil respiration: pathways, mechanisms, and significance for global change. Biogeosciences 8, 2047-2061. doi: 10.5194/bg-8-2047-2011

Mitchell, E. A. D., Belbahri, L., Job, D., Pawlowski, D., and Lara, E. (2011). Exploring the Terra incognita of unknown eukaryotic diversity in Soils - A major challenge we now have the tools to tackle! Bull. BGS 32, 57-62.

Mitchell, R. J., Campbell, C. D., Chapman, S. J., and Cameron, C. M. (2010). The ecological engineering impact of a single tree species on the soil microbial community. J. Ecol. 98, 50-61. doi: 10.1111/j.1365-2745.2009. 01601.x

Money, N. M. (2016). Are mushrooms medicinal? Fungal Biol. 120, 449-453. doi: 10.1016/j.funbio.2016.01.006

Mueller, K. E., Eisenhauer, N., Reich, P. B., Hobbie, S. E., Chadwick, O. A., Chorover, J., et al. (2016). Light, earthworms, and soil resources as predictors of diversity of 10 soil invertebrate groups across monocultures of 14 tree species. Soil Biol. Biochem. 92, 184-198. doi: 10.1016/j.soilbio.2015.10.010

Nielsen, U. N., Ayres, E., Wall, D. H., and Bardgett, R. D. (2011). Soil biodiversity and carbon cycling: a review and synthesis of studies examining diversity-function relationships. Eur. J. Soil Sci. 62, 105-116. doi: $10.1111 /$ j.1365-2389.2010.01314.x

Nielsen, U. N., Osler, G. H. R., Campbell, C. D., Burslem, D. F. R. P., and van der Wal, R. (2012). Predictors of fine-scale spatial variation in soil mite and microbe community composition differ between biotic groups and habitats. Pedobiologia 55, 83-91. doi: 10.1016/j.pedobi.2011.11.002

Nielsen, U. N., Wall, D. H., and Six, J. (2015). Soil biodiversity and the environment. Annu. Rev. Env. Resour. 40, 63-90. doi: 10.1146/annurev-environ-102014-021257

Oliver, T. H., Heard, M. S., Isaac, N. J. B., Roy, D. B., Procter, D., Eigenbrod, F., et al. (2015). Biodiversity and resilience of ecosystem functions. Trends Ecol. Evol. 30, 673-684. doi: 10.1016/j.tree.2015.08.009

Peres, G., Cluzeau, D., Curmi, P., and Hallaire, V. (1998). Earthworm activity and soil structure changes due to organic enrichments in vineyard systems. Biol. Fertil. Soils 27, 417-424. doi: 10.1007/s0037400 50452

Phillips, D. H., and FitzPatrick, E. A. (1999). Biological influences on the morphology and micromorphology of selected Podzols (Spodosols) and Cambisols (Inceptisols) from the eastern United States and north-east Scotland. Geoderma 90, 327-364. doi: 10.1016/S0016-7061(98)00121-9

Ponge, J. F., Gillet, S., Dubs, F., Fédorof, E., Haese, L., Sousa, J. P., et al. (2003). Collembolan communities as bioindicators of land use intensification. Soil Biol. Biochem. 35, 813-826. doi: 10.1016/S0038-0717(03) 00108-1

Potapov, A.A., Semenina, E.E., Korotkevich, A.Y., Kuznetsova, N.A., and Tiunov, A.V. (2016). Connecting taxonomy and ecology: trophic niches of collembolans as related to taxonomic identity and life forms. Soil Biol. Biochem. 101, 20-31. doi: 10.1016/j.soilbio.2016.07.002

Pretzsch, H., Bielak, K., Block, J., Bruchwald, A., Dieler, J., Ehrhart, H. P., et al. (2013). Productivity of mixed versus pure stands of oak (Quercus petraea (Matt.) Liebl. and Quercus robur L.) and European beech (Fagus sylvatica L.) along an ecological gradient. Eur. J. For. Res. 132, 263-280. doi: 10.1007/s10342-012-0673-y

Pretzsch, H., and Zenner, E. K. (2017). Toward managing mixed-species stands: from parametrization to prescription. For. Ecosyst. 4:19. doi: $10.1186 / \mathrm{s} 40663-017-0105-\mathrm{z}$

Rajala, T., Peltoniemi, M., Pennanen, T., and Makipaa, R. (2012). Fungal community dynamics in relation to substrate quality of decaying Norway spruce (Picea abies [L.] Karst.) logs in boreal forests. FEMS Microbiol. Ecol. 81, 494-505. doi: 10.1111/j.1574-6941.2012. 01376.x

Rajapakshaa, N. S. S., Butt, K. R., Vanguelova, E. I., and Moffat, A. J. (2014). Short rotation forestry - Earthworm interactions: a field based mesocosm experiment. Appl. Soil Ecol. 76, 52-59. doi: 10.1016/j.apsoil.2013. 12.008

Ramesh, M. A. (2016). Inoculating curiosity in fungal biology for a new generation of students. Fungal Biol. Rev. 30, 15-23. doi: 10.1016/j.fbr.2016. 03.001

Rantalainen, M.L., Haimi, J., Fritze, H., Pennanen, T., and Setälä, H. (2008). Soil decomposer community as a model system in studying the effects of habitat fragmentation and habitat corridors. Soil Biol. Biochem. 40, 853-863. doi: 10.1016/j.soilbio.2007.11.008

Ratcliffe, S., Wirth, C., Jucker, T., van der Plas, F., Scherer-Lorenzen, M., Verheyen, K., et al. (2017). Biodiversity and ecosystem functioning relations in European forests depend on environmental context. Ecol. Lett. 20, 1414-1426. doi: $10.1111 /$ ele. 12849

Read, D.J., and Perez-Moreno, J. (2003). Mycorrhizas and nutrient cycling in ecosystems: a journey towards relevance? New Phytol. 157, 475-492. doi: 10.1046/j.1469-8137.2003.00704.x

Read, D. J. (1991). Mycorrhizas in ecosystems. Experientia 47, 376-390. doi: $10.1007 / \mathrm{BF} 01972080$

Reis, F., Carvalho, F., Martins da Silva, P., Mendes, S., Santos, S.A. P., and Sousa, J.P. (2016). The use of a functional approach as surrogate of Collembola species richness in European perennial crops and forests. Ecol. Indic. 2, 676-682. doi: 10.1016/j.ecolind.2015.10.019

Rillig, M.C. (2004). Arbuscular mycorrhizae and terrestrial ecosystem processes. Ecol. Lett. 7, 740-754. doi: 10.1111/j.1461-0248.2004.00620.x

Rockström, J., Steffen, W., Noone, K., Persson, A., Chapin, F.S., 3rd, Lambin, E. F., et al. (2009). A safe operating space for humanity. Nature 461, 472-475. doi: $10.1038 / 461472 \mathrm{a}$

Rossetti, I., Bagella, S., Cappai, C., Caria, M.C., Lai, R., Roggero, P.P., et al. (2015). Isolated cork oak trees affect soil properties and biodiversity in a Mediterranean wooded grassland. Agr. Ecosyst. Environ. 202, 203-216. doi: 10.1016/j.agee.2015.01.008

Rusek, J. (1998). Biodiversity of Collembola and their functional role in the ecosystem. Biodiv. Conserv. 7, 1207-1219. doi: 10.1023/A:10088878 17883

Rutter, G. (2010). "Fungi and humanity," in From Another Kingdom. The Amazing World of Fungi, eds. L. Boddy and M. Coleman (Edinburgh: RBG), 93-104.

Salamon, J. A., Scheu, S., and Schaefer, M. (2008). The Collembola community of pure and mixed stands of beech (Fagus sylvatica) and spruce (Picea abies) of different age. Pedobiologia 51, 385-396. doi: 10.1016/j.pedobi.2007. 10.002

Salamon, J. A., and Wolters, V. (2009). Nematoda response to forest conversion. Eur. J. Soil Biol. 45, 184-191. doi: 10.1016/j.ejsobi.2008.09.014

Salminen, J., Hernesmaa, A., Karjalainen, H., Fritze, H., and Romantschuk, M. (2010). Activity of nematodes and enchytraeids, bacterial community composition, and functional redundancy in coniferous forest soil. Biol. Fertil. Soils 46, 113-126. doi: 10.1007/s00374-009-0409-4

Šarič-Kundalič, B., Dobeš, C., Klatte-Asselmeyer, V., and Saukel, J. (2010). Ethnobotanical study on medicinal use of wild and cultivated plants in middle, south and west Bosnia and Herzegovina. J. Ethnopharmacol. 131, 33-55. doi: 10.1016/j.jep.2010.05.061

Sax, B. (2001). The Mythical Zoo: An Encyclopedia of Animals in World Myth, Legend, and Literature - Beaver, Porcupine, Badger, and Miscellaneous Rodents. Santa Barbara: ABC-CLIO.

Schaefer, M., and Schauermann, J. (1990). The soil fauna of beech forests: comparison between a mull and a moder soil. Pedobiologia 34, 299-314.

Scheu, S. (2003). Effects of earthworms on plant growth: patterns and perspectives. Pedobiologia 47, 846-856. doi: 10.1078/0031-4056-00270

Schleuß, P.-M., Heitkamp, F., Leuschner, C., Fender, A.-C., and Jungkunst, H.F. (2014). Higher subsoil carbon storage in speciesrich than species-poor temperate forests. Environ. Res. Lett. 9:014007. doi: 10.1088/1748-9326/9/1/014007

Scholes, R., Biggs, R., Palm, C., and Duraiappah, A. (2010). "Assessing state and trends in ecosystem services and human well-being," in Ecosystems and WellBeing: A Manual for Assessment Practitioners, eds. N. Ash, H. Blanco, C. Brown, K. Garcia, T. Henrichs, N. Lucas, et al. (Washington: Island Press), $115-150$. 
Schröter, D., Wolters, V., and De Ruiter, P. C. (2003). C and N mineralisation in the decomposer food webs of a European forest transect. Oikos 102, 294-308. doi: 10.1034/j.1600-0579.2003.12064.x

Science for Environment Policy (2015). Ecosystem Services and the Environment. In-depth Report 11. Bristol: European Commission, DG Environment by the Science Communication Unit, UWE. Available online at: http://ec.europa.eu/ science-environment-policy.

Setälä, H., and McLean, M. A. (2004). Decomposition rate of organic substrates in relation to the species diversity of soil saprophytic fungi. Oecologia 139, 98-107. doi: $10.1007 / \mathrm{s} 00442-003-1478-y$

Shipitalo, M.J., and Butt, K.R. (1999). Occupancy and geometrical properties of Lumbricus terrestris L. burrows affecting infiltration. Pedobiologia 43, 782-794.

Silvertown, J. (2015). Have ecosystem services been oversold? Trends Ecol. Evol. 30, 641-648. doi: 10.1016/j.tree.2015. 08.007

Sisak, L., Riedl, M., and Dudik, R. (2016). Non-market non-timber forest products in the Czech Republic-Their socio-economic effects and trends in forest land use. Land Use Pol. 50, 390-398. doi: 10.1016/j.landusepol.2015.10.006

Spiecker, H. (2003). Silvicultural management in maintaining biodiversity and resistance of forests in Europe-temperate zone. J. Environ. Manag. 67, 55-65. doi: 10.1016/S0301-4797(02)00188-3

Spooner, B., and Læssøe, T. (1994). The folklore of 'gasteromycetes'. Mycologist $8,119-123$.

Stryamets, N., Elbakidze, M., Ceuterick, M., Angelstam, P., and Axelsson, R. (2015). From economic survival to recreation: contemporary uses of wild food and medicine in rural Sweden, Ukraine and NW Russia. J. Ethnobiol. Ethnomed. 11:53. doi: 10.1186/s13002-015-0036-0

Summerbell, R. C. (2005). From Lamarckian fertilizers to fungal castles: recapturing the pre-1985 literature on endophytic and saprotrophic fungi associated with ectomycorrhizal root systems. Stud. Mycol. 53, 191-256. doi: $10.3114 /$ sim.53.1.191

Swift, M. J., Andren, O., Brussaard, L., Briones, M., Couteaux, M. M., Ekschmitt, K., et al. (1998). Global change, soil biodiversity, and nitrogen cycling in terrestrial ecosystems: three case studies. Glob. Change Biol. 4, 729-743. doi: 10.1046/j.1365-2486.1998.00207.x

Tallis, H., and Polasky, S. (2009). Mapping and valuing ecosystem services as an approach for conservation and natural resources management. Ann. N. Y. Acad. Sci. 1162, 265-283. doi: 10.1111/j.1749-6632.2009. 04152.x

TEEB (2010). "The Economics of Ecosystems and Biodiversity. Ecological and Economic Foundations," ed. P. Kumar (Abingdon: Routledge), 410.

Temraleeva, A. D., Pinskii, D. L., Patova, E. N., and Spirina, E. V. (2011). The use of algae-cyanobacterial communities for the assessment of lead pollution of gray forest soils. Eurasian Soil Sci. 44, 326-331. doi: 10.1134/S10642293110 30136

Tikhonenkov, D. V., Mazei, Y. A., and Embulaeva, E. A. (2011). The species composition and structure of the heterotrophic flagellates in forest steppe soils of the middle Volga river basin. Eurasian Soil Sci. 44, 194-203. doi: $10.1134 /$ S1064229311020153

Tiunov, A. V., and Scheu, S. (2005). Facilitative interactions rather than resource partitioning drive diversity-functioning relationships in laboratory fungal communities. Ecol. Lett. 8, 618-625. doi: 10.1111/j.1461-0248.2005. 00757.x

Tremolières, M., Sanchez-Perez, J. M., Schnitzler, A., and Schmitt, D. (1998). Impact of river management history on the community structure, species composition and nutrient status in the Rhine alluvial hardwood forest. Plant Ecol. 135, 59-78. doi: 10.1023/A:1009756428824

Trestrail, J. H III. (2000). "Poisoning in fiction," in Criminal Poisoning, ed. J. H. Trestrail III (New York, NY: Springer), 93-97. doi: 10.1007/978-1-59259-023-0_9

Trinkauske, E. (2008). Seeing the Swarming Dead: of Mushrooms, Trees, and Bees. New York, NY: Proquest; Umi Dissertation Publishing; Syracuse University. 284.

Turner, N. J., Łuczaj, Ł. J., Migliorini, P., Pieroni, A., Dreon, A. L., Sacchetti, L.E., et al. (2011). Edible and tended wild plants, traditional ecological knowledge and agroecology. Crit. Rev. Plant Sci. 30:198-225. doi: 10.1080/07352689.2011.5 54492
Ulicsni, V., Svanberg, I., and Molnár, Z. (2016). Folk knowledge of invertebrates in Central Europe - folk taxonomy, nomenclature, medicinal and other uses, folklore, and nature conservation. J. Ethnobiol. Ethnomed. 12:47doi: 10.1186/s13002-016-0118-7

Urbanovičová, V., Miklisová, D., and Kováč, L. (2014). Forest disturbance enhanced the activity of epedaphic collembola in windthrown stands of the High Tatra mountains. J. Mt. Sci. 11, 449-463. doi: 10.1007/s11629-01 3-2736-z

Uroz, S., Calvaruso, C., Turpault, M. P., Pierrat, J. C., Mustin, C., and FreyKlett, P. (2007). Effect of the mycorrhizosphere on the genotypic and metabolic diversity of the bacterial communities involved in mineral weathering in a forest soil. Appl. Environ. Microbiol. 73, 3019-3027. doi: 10.1128/AEM.00 121-07

Uroz, S., Oger, P., Lepleux, C., Collignon, C., Frey-Klett, P., and Turpault, M. P. (2011). Bacterial weathering and its contribution to nutrient cycling in temperate forest ecosystems. Res Microbiol. 162, 820-831. doi: 10.1016/j.resmic.2011.01.013

Ushio, M., Miki, T., and Balser, T. C. (2013). A coexisting fungalbacterial community stabilizes soil decomposition activity in a microcosm experiment. PLOS ONE 8:e80320. doi: 10.1371/journal.pone.00 80320

van der Heijden, M. G. A., Bardgett, R. D., and van Straalen, N. M. (2008). The unseen majority: soil microbes as drivers of plant diversity and productivity in terrestrial ecosystems. Ecol. Lett. 11, 296-310. doi: 10.1111/j.1461-0248.2007.01139.x

van der Heijden, M. G. A., Martin, F. M., Selosse, M.-A., and Sanders, I. R. (2015). Mycorrhizal ecology and evolution: the past, the present, and the future. New Phytol. 205, 1406-1423. doi: 10.1111/nph.13288

van der Plas, F., Manning, P., Allan, E., Scherer-Lorenzen, M., Verheyen, K., Wirth, C., et al. (2016). Jack-of-all-trades effects drive biodiversity-ecosystem multifunctionality relationships in European forests. Nat. Comm. 7:11109. doi: 10.1038/ncomms11109

van Hooff, P. (1983). Earthworm activity as a cause of splash erosion in a Luxembourg forest. Geoderma 31, 195-204. doi: 10.1016/0016-7061(83)90013-7

Velmala, S. M., Rajala, T., Haapanen, M., Taylor, A. F. S., and Pennanen, T. (2013). Genetic host-tree effects on the ectomycorrhizal community and root characteristics of Norway spruce. Mycorrhiza 23, 21-33. doi: 10.1007/s00572-012-0446-y

Velmala, S. M., Rajala, T., Heinonsalo, J., Taylor, A. F. S., and Pennanen, T. (2014). Profiling functions of ectomycorrhizal diversity and root structuring in seedlings of Norway spruce (Picea abies) with fast- and slow growing phenotypes. New Phytol. 201, 610-622. doi: 10.1111/nph.12542

Vesterdal, L., Clarke, N., Sigurdsson, B. D., and Gundersen, P. (2013). Do tree species influence soil carbon stocks in temperate and boreal forests? For. Ecol. Manage. 309, 4-18. doi: 10.1016/j.foreco.2013.01.017

Vilà, M., Vayreda, J., Gracia, C., and Ibañez, J. (2004). Biodiversity correlates with regional patterns of forest litter pools. Oecologia 139, 641-646. doi: 10.1007/s00442-004-1546-y

Violle, C., Reich, P. B., Pacala, S. W., Enqist, B. J., and Kattke, J. (2014). The emergence and promise of functional biogeography. Proc. Natl. Acad. Sci. U.S.A. 111, 13690-13696. doi: 10.1073/pnas.1415442111

Vogl, S., Picker, P., Mihaly-Bison, J., Fakhrudin, N., Atanasov, A. G., Heiss, E. H., et al. (2013). Ethnopharmacological in vitro studies on Austria's folk medicine - An unexplored lore in vitro anti-inflammatory activities of 71 Austrian traditional herbal drugs. J. Ethnopharmacol. 149, 750-771. doi: 10.1016/j.jep.2013.06.007

Vos, V. C. A., van Ruijven, J., Berg, M. P., Peeters, E., and Berendse, F. (2011). Macro-detritivore identity drives leaf litter diversity effects. Oikos 120 1092-1098. doi: 10.1111/j.1600-0706.2010.18650.x

Wasson, V. P., and Wasson, R. G. (1957). Mushrooms, Russia and History. New York, NY: Pantheon Books.

Wilkinson, A., Alexander, I. J., and Johnson, D. (2011). Species richness of ectomycorrhizal hyphal necromass increases soil $\mathrm{CO}_{2}$ efflux under laboratory conditions. Soil Biol. Biochem. 43, 1350-1355. doi: 10.1016/j.soilbio.2011.03.009

Wilkinson, A., Solan, M., Alexander, I., and Johnson, D. (2012). Species richness and nitrogen supply regulate the productivity and respiration 
of ectomycorrhizal fungi in pure culture. Fungal Ecol. 5, 211-222. doi: 10.1016/j.funeco.2011.08.007

Wright, J. (2010). "The fungal forager," in From Another Kingdom. The Amazing World of Fungi, eds. L. Boddy and M. Coleman (Edinburgh: RBG), 131-142.

Yamin-Pasternak, S. (2008). A means of survival, a marker of feasts: mushroom cookery in the Russian Far East. Ethnology 47, 95-107. Available online at: https://www.jstor.org/stable/25651552

Yamin-Pasternak, S. (2011). "Ethnomycology: mushrooms in cultural entanglements," in Ethnobiology, a Textbook, eds. E. N. Anderson and N. Turner (Hoboken, NJ: Wiley Blackwell Publications), 213-230. doi: 10.1002/9781118 015872.ch13

Yang, G., Wagg, C., Veresoglou, S. D., Hempel, S., and Rillig, M. C. (2019). How soil biota drive ecosystem stability. Trends Plant. Sci. 23, 1057-1067. doi: 10.1016/j.tplants.2018.09.007

You, Y. M., Wang, J., Huang, X. M., Tang, Z. X., Liu, S. R., and Sun, O. J. (2013). Relating microbial community structure to functioning in forest soil organic carbon transformation and turnover. Ecol. Evol. 4, 633-647. doi: $10.1002 /$ ece3.969
Zeithaml, J., Pizl, V., and Sklenicka, P. (2009). Earthworm assemblages in an ecotone between forest and arable field and their relations with soil properties. Pesq. Agropec. Bras. 44, 922-927. doi: 10.1590/S0100-204X2009 000800018

Conflict of Interest Statement: The authors declare that the research was conducted in the absence of any commercial or financial relationships that could be construed as a potential conflict of interest.

Copyright (C) 2019 Bakker, Brunner, Ashwood, Bjarnadottir, Bolger, Børja, Carnol, Cudlin, Dalsgaard, Erktan, Godbold, Kraigher, Meier, Merino-Martín, Motiejūnaitè, Mrak, Oddsdóttir, Ostonen, Pennanen, Püttsepp, Suz, Vanguelova, Vesterdal and Soudzilovskaia. This is an open-access article distributed under the terms of the Creative Commons Attribution License (CC BY). The use, distribution or reproduction in other forums is permitted, provided the original author(s) and the copyright owner(s) are credited and that the original publication in this journal is cited, in accordance with accepted academic practice. No use, distribution or reproduction is permitted which does not comply with these terms. 